\title{
REVIEW
}

\section{The dopamine hypothesis of bipolar affective disorder: the state of the art and implications for treatment}

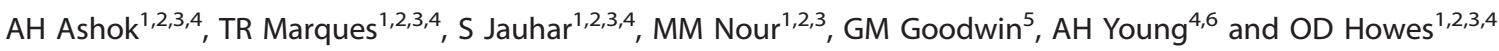

\begin{abstract}
Bipolar affective disorder is a common neuropsychiatric disorder. Although its neurobiological underpinnings are incompletely understood, the dopamine hypothesis has been a key theory of the pathophysiology of both manic and depressive phases of the illness for over four decades. The increased use of antidopaminergics in the treatment of this disorder and new in vivo neuroimaging and post-mortem studies makes it timely to review this theory. To do this, we conducted a systematic search for post-mortem, pharmacological, functional magnetic resonance and molecular imaging studies of dopamine function in bipolar disorder. Converging findings from pharmacological and imaging studies support the hypothesis that a state of hyperdopaminergia, specifically elevations in D2/3 receptor availability and a hyperactive reward processing network, underlies mania. In bipolar depression imaging studies show increased dopamine transporter levels, but changes in other aspects of dopaminergic function are inconsistent. Puzzlingly, pharmacological evidence shows that both dopamine agonists and antidopaminergics can improve bipolar depressive symptoms and perhaps actions at other receptors may reconcile these findings. Tentatively, this evidence suggests a model where an elevation in striatal D2/3 receptor availability would lead to increased dopaminergic neurotransmission and mania, whilst increased striatal dopamine transporter (DAT) levels would lead to reduced dopaminergic function and depression. Thus, it can be speculated that a failure of dopamine receptor and transporter homoeostasis might underlie the pathophysiology of this disorder. The limitations of this model include its reliance on pharmacological evidence, as these studies could potentially affect other monoamines, and the scarcity of imaging evidence on dopaminergic function. This model, if confirmed, has implications for developing new treatment strategies such as reducing the dopamine synthesis and/or release in mania and DAT blockade in bipolar depression.
\end{abstract}

Molecular Psychiatry (2017) 22, 666-679; doi:10.1038/mp.2017.16; published online 14 March 2017

\section{INTRODUCTION}

Bipolar disorder (BD) is a severe mental illness characterised by recurrent episodes of mania, depression or mixed states. ${ }^{1,2}$ The lifetime prevalence of the full spectrum of bipolar disorder is estimated to be $2-4 \%$ in the general population and it is the sixth leading cause of disability worldwide. ${ }^{3-6}$ The costs due to BD are immense, with annual direct healthcare costs in the USA of about $\$ 30$ billion and indirect costs of $>\$ 120$ billion. ${ }^{7,8}$

Lithium has been the mainstay of maintenance treatment for $\mathrm{BD}$ for decades, together with valproate, an option that has emerged more recently. However their modes of action have not been well established. By contrast antidopaminergic drugs do have well-understood class action at D2/3 receptors and have long been used to treat acute manic episodes. However, as will be explained below, newer drugs (particularly olanzapine and quetiapine) have been shown to have antimanic and antidepressant actions in bipolar disorder together with long-term benefit in preventing relapse to either pole of the illness. ${ }^{9-15}$ Although the newer drugs were introduced for the treatment of schizophrenia, they have arguably represented a bigger advance for the management of bipolar disorder.
Despite these advances in treatment, many patients continue to experience high levels of disability. ${ }^{11}$ Furthermore drugs may be associated with significant side-effect burden and the risk of toxicity and/or teratogenicity in some instances. ${ }^{16-18}$ Hence better understanding of pathophysiology and drug action appears necessary to improve the use of current treatments and develop better alternatives.

The dopamine hypothesis of BD dates back at least to the 1970s. ${ }^{19-21}$ Early incarnations focused on mania, and the parallels between the behavioural consequences of amphetamine ingestion and the antimanic actions of antidopaminergic drugs. If hyperdopaminergia underlies the development of manic symptoms, then hypodopaminergia might underlie the depressive phase of the illness. Thus, opposite changes in dopaminergic function were hypothesised to underlie the opposing affective poles of the disorder. ${ }^{19-21}$ This theory did not explain how hyper- or hypodopaminergia would arise and subsequent versions proposed an additional component to the hypothesis, where an intrinsic dysregulation in the homoeostatic regulation of dopaminergic function leads to cyclical changes in dopaminergic neurotransmission, ${ }^{22,23}$ which would further distinguish the

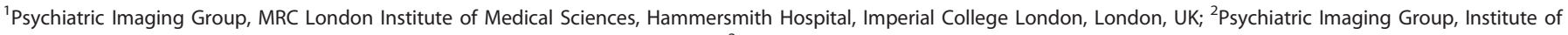

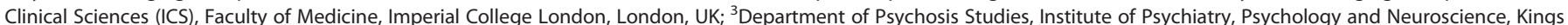

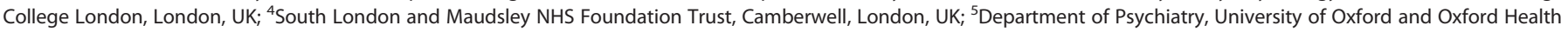

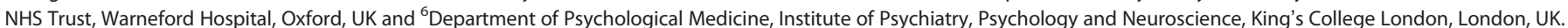

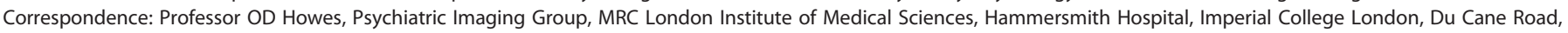
London W12 0NN, UK. 


\begin{tabular}{|c|c|c|c|c|c|c|c|c|c|}
\hline Measure of & Author & $\begin{array}{l}\text { Bipolar patients/ } \\
\text { controls }(\mathrm{n})\end{array}$ & $\begin{array}{l}\text { Bipolar } \\
\text { patients/ } \\
\text { controls age } \\
\text { mean (s.d.) in } \\
\text { years }\end{array}$ & Method & Area & $\begin{array}{l}\text { Cause of } \\
\text { death } \\
\text { patients/ } \\
\text { controls }\end{array}$ & Patients' medication & $\begin{array}{l}\text { Post-mortem } \\
\text { interval (h): } \\
\text { patients/ } \\
\text { controls }\end{array}$ & $\begin{array}{l}\text { Results ( } B D \text { relative to } \\
\text { controls) }\end{array}$ \\
\hline \multirow[t]{2}{*}{$\begin{array}{l}\text { Dopamine } \\
\text { transporter }\end{array}$} & Rao et al..$^{134}$ & $10 / 10$ & $\begin{array}{c}55 \text { (s.e.m.: } \\
6.6) / 49 \\
\text { (s.e.m.: } 4.3 \text { ) }\end{array}$ & $\begin{array}{l}\text { Western blot analysis, RNA } \\
\text { isolation, RT-PCR }\end{array}$ & Prefrontal Cortex & $\begin{array}{l}\text { Not } \\
\text { mentioned }\end{array}$ & $\begin{array}{l}\text { Lithium: } 4 \\
\text { Valproate: } 5 \\
\text { Rispiridone: } 1 \\
\text { Carbamazepine: } 1\end{array}$ & $21 / 20$ & $\begin{array}{l}\downarrow \text { DAT protein and } \\
\text { mRNA levels }\end{array}$ \\
\hline & Lee et al. ${ }^{135}$ & $15 / 15$ & $\begin{array}{l}42.3(9.3) / 48 \\
(10.7)\end{array}$ & $\begin{array}{l}\text { Coimmunoprecipitation and } \\
\text { Western blot analyses }\end{array}$ & Striatum & $\begin{array}{l}\text { Suicide- } 9 / 0 \\
\text { Non suicidal- } \\
6 / 15\end{array}$ & $\begin{array}{l}\text { Dopamine antagonist: } \\
7\end{array}$ & $33 / 24$ & $\begin{array}{l}\leftrightarrow \text { DAT protein } \\
\text { levels }\end{array}$ \\
\hline \multirow[t]{2}{*}{$\begin{array}{l}\text { Dopamine } \\
\text { D1 receptor }\end{array}$} & $\begin{array}{l}\text { Pantazopoulos } \\
\text { et al. } .^{37}\end{array}$ & $15 / 15$ & $58.3 / 61.3$ & In situ hybridisation & Hippocampus & $\begin{array}{l}\text { Suicide- } 3 / 0 \\
\text { Non suicidal- } \\
12 / 15\end{array}$ & $\begin{array}{l}\text { Dopamine antagonist: } \\
8\end{array}$ & $21 / 20$ & $\begin{array}{l}\uparrow D 1 \text { mRNA } \\
\text { expression in } \\
\text { hippocampal sector } \\
\text { CA2 }\end{array}$ \\
\hline & Kaalund et al. ${ }^{34}$ & $\begin{array}{l}\text { DLPFC 61/ } 244 \\
\text { Hippocampus } \\
31 / 192 \\
\text { Caudate nucleus } \\
44 / 78\end{array}$ & $\begin{array}{l}45 / 40 \\
46 / 40 \\
43 / 41\end{array}$ & $\begin{array}{l}\text { RNA extraction and } \\
\text { Quantitative real-time PCR }\end{array}$ & $\begin{array}{l}\text { DLPFC, } \\
\text { hippocampus } \\
\text { and caudate }\end{array}$ & $\begin{array}{l}\text { Not } \\
\text { mentioned }\end{array}$ & $\begin{array}{l}\text { Dopamine antagonist: } \\
17\end{array}$ & $\begin{array}{l}\text { Not } \\
\text { mentioned }\end{array}$ & $\begin{array}{l}\uparrow \mathrm{DRD} 1 \text { in DLPFC } \\
\text { and hippocampus. } \\
\leftrightarrow \text { caudate nucleus }\end{array}$ \\
\hline \multirow[t]{4}{*}{$\begin{array}{l}\text { Dopamine } \\
\text { D2 receptor }\end{array}$} & Zhan et al..$^{35}$ & $32 / 34$ & $45(10) / 43(7)$ & Quantitative real-time PCR & Prefrontal cortex & $\begin{array}{l}\text { Sucide- } 15 / 0 \\
\text { Non suicidal } \\
\text { causes-17/34 }\end{array}$ & $\begin{array}{l}\text { Mean lifetime } \\
\text { antidopaminergic } \\
\text { exposure: } \\
10071 \mathrm{mg} \\
\text { fluphenazine } \\
\text { equivalent }\end{array}$ & $37 / 29$ & $\begin{array}{l}\uparrow \mathrm{D} 2 \text { mRNA level in } \\
\text { prefrontal cortex }\end{array}$ \\
\hline & Glantz et al. ${ }^{36}$ & $14 / 14$ & $\begin{array}{l}42.3(11.7) / \\
48.1(10.7)\end{array}$ & $\begin{array}{l}\text { Western blot analysis and } \\
\text { immunohistochemistry }\end{array}$ & Temporal Cortex & $\begin{array}{l}\text { Suicide-9/0 } \\
\text { Non suicidal- } \\
6 / 15\end{array}$ & $\begin{array}{l}\text { Lithium: } 4 \\
\text { Dopamine antagonist: } \\
8 \\
\text { Antidepressant: } 8\end{array}$ & $33 / 24$ & $\leftrightarrow$ \\
\hline & Kaalund et al. ${ }^{34}$ & $\begin{array}{l}\text { DLPFC } 61 / 244 \\
\text { Hippocampus } \\
31 / 192 \\
\text { Caudate nucleus } \\
44 / 78\end{array}$ & $\begin{array}{l}45 / 40 \\
46 / 40 \\
43 / 41\end{array}$ & $\begin{array}{l}\text { RNA extraction and } \\
\text { Quantitative real-time PCR }\end{array}$ & $\begin{array}{l}\text { DLPFC, } \\
\text { hippocampus } \\
\text { and caudate }\end{array}$ & $\begin{array}{l}\text { Not } \\
\text { mentioned }\end{array}$ & $\begin{array}{l}\text { Dopamine antagonist: } \\
17\end{array}$ & $\begin{array}{l}\text { Not } \\
\text { mentioned }\end{array}$ & $\begin{array}{l}\uparrow D 2 L \text { in DLPFC and } \\
\text { hippocampus } \\
\leftrightarrow \text { Caudate nucleus }\end{array}$ \\
\hline & Lee et al. ${ }^{135}$ & $15 / 15$ & $\begin{array}{l}42.3(9.3) / 48 \\
(10.7)\end{array}$ & $\begin{array}{l}\text { Coimmunoprecipitation and } \\
\text { Western blot analyses }\end{array}$ & Striatum & $\begin{array}{l}\text { Suicide-9/0 } \\
\text { Non suicidal- } \\
6 / 15\end{array}$ & $\begin{array}{l}\text { Dopamine antagonist: } \\
7\end{array}$ & $33 / 24$ & $\leftrightarrow$ D2 protein levels \\
\hline D5 receptor & Knable et al. ${ }^{38}$ & 48 data sets & & In situ hybridisation & Hippocampus & $\begin{array}{l}\text { Not } \\
\text { mentioned }\end{array}$ & Not mentioned & $\begin{array}{l}\text { Not } \\
\text { mentioned }\end{array}$ & $\begin{array}{l}\uparrow \text { Dopamine D5 } \\
\text { receptor RNA in } \\
\text { dentate gyrus, CA1 } \\
\text { and subiculum }\end{array}$ \\
\hline
\end{tabular}


dopamine hypothesis of bipolar from theories of schizophrenia. ${ }^{24}$ Thus, faulty homoeostatic mechanisms responding to hyperdopaminergia in the manic phase of the illness are proposed to result in an excessive reduction in dopaminergic function, rapidly leading to a hypodopaminergic state and depression. In turn a faulty regulatory response to hypodopaminergia leads, to a switch back to mania. 22,23 Implicit in this model is that a normalisation of dopaminergic function leads to remission and euthymia. Clearly, some kind of dysregulation must be required to account for the onset of episodes, but BD is also characterised by inter-episode mood instability. ${ }^{25}$ Any satisfactory theory must account for the randomness of much bipolar experience as well as the cyclicity. As current antimanic antipsychotics are all dopamine D2 receptor blockers, their use for mania has long supported the involvement of dopamine in mania, but the increasing use of some antidopaminergic drugs to treat bipolar depression and as maintenance drugs makes it timely to review the dopamine hypothesis of BD. Furthermore, a number of new lines of evidence relevant to the role of dopamine, in particular from molecular and functional neuroimaging, have developed in recent years. Thus, we synthesize evidence from pharmacological, in vivo neuroimaging and postmortem studies addressing the role of the dopamine system in BD and then consider the treatment and drug development implications.

\section{ANIMAL MODELS AND THEIR IMPLICATIONS FOR UNDERSTANDING THE ROLE OF DOPAMINE IN BIPOLAR DISORDER}

Initial animal models of mania were based on amphetamineinduced hyperlocomotion, and it was shown that lithium reverses this behaviour. ${ }^{26,27}$ Following this, a dopamine transporter (DAT) knockout rodent model was developed, and dopamine transporter blockers other than amphetamine (such as GBR12909) have been used. Both these approaches have been shown to induce manic-like behaviour, such as hyperlocomotion and increased exploration. ${ }^{28,29}$ Subsequently, dopamine receptor stimulation using quinipirole (a dopamine agonist) was shown to induce manic-like behaviour. ${ }^{30}$ Interestingly, mood stabilisers such as valproate and carbamazepine reversed these effects. ${ }^{30}$ Recently, Sidor and colleagues demonstrated the impact of alterations in the regulation of circardian rhythm on dopaminergic activity and behaviour. ${ }^{31}$ In this study, mice with a mutation in a circadian clock gene displayed a manic-like phenotype as measured by hyperlocomotion in the daytime. Moreover, hyperlocomotion was linked to an elevated daytime spike in ventral tegmental area (VTA) dopaminergic activity, as well as increased dopamine synthesis and tyrosine hydroxylase activity. ${ }^{31}$ This was further validated using sustained optogenetic stimulation of the VTA, which also induced hyperlocomotion behaviour. ${ }^{31}$ Taken together this evidence suggests that hyperdopaminergia, induced either by increased dopamine release, dopamine transporter blockade or dopamine receptor stimulation, results in a mania-like phenotype in rodents. In contrast, lesions in dopaminergic areas (such as the VTA and substantia nigra) induce depressive behaviour, such as learned helplessness. ${ }^{32}$ Moreover, optogenetic stimulation of VTA dopaminergic neurons reverses depressive behaviour (as assessed using the forced swim test in chronically stressed animals). ${ }^{33}$ These models thus provide evidence that hypodopaminergia may induce depressive-like behaviours and hyperdopaminergia may induce manic-like behaviour. Further research is needed to determine the key components of the dopaminergic circuit underlying this, particularly in relation to depressive behaviour.

\section{POST-MORTEM STUDIES ON DOPAMINE GENE EXPRESSION IN BIPOLAR DISORDER}

Table 1 shows the post-mortem studies addressing dopaminergic gene expression in $\mathrm{BD}$. Overall the most consistent findings come from studies on the D2 receptor expression, with two studies suggesting that the D2 receptor is upregulated in BD in the dorsolateral prefrontal cortex. ${ }^{34,35}$ However, to date only four studies, ${ }^{28,30,34,36}$ have been conducted, and only two focus on the same region (dorsolateral prefrontal cortex). Thus, this finding still requires replication in other brain regions to determine if there is regional specificity. The literature on other dopaminergic receptors is more limited, with only two studies on the D1 receptor ${ }^{34,37}$ and one study on the D5 receptor. ${ }^{38}$ Another issue for the postmortem studies is that they are affected by several confounding factors such as medication status, post-mortem interval, substance abuse and cause of death. Antidopaminergic treatment has been shown to increase D2/3 receptor levels in animals, ${ }^{39}$ and there is evidence this may also occur in schizophrenia. ${ }^{40}$ This suggests that prior treatment could also have affected the D2/3 receptor findings in BD. Finally, data on phase-specific changes are difficult to characterise as clinical status at the time of death remains unknown. Despite these limitations, post-mortem data supports the notion that an abnormality within the dopaminergic pathways, in particular involving D2/3 receptors, might play a role in the pathogenesis of BD.

\section{IN VIVO IMAGING OF DOPAMINE}

\section{Dopamine in mania}

We have summarised the in vivo imaging studies of mania in Table 2. Interestingly, patients with psychotic mania showed an elevated density of D2/3 receptors as measured by $\mathrm{N}-\left[{ }^{11} \mathrm{C}\right]-$ methylspiperone, when compared with healthy controls $(\mathrm{HC})$ and non-psychotic mania patients, ${ }^{41,42}$ although, as this tracer has significant affinity for $5 \mathrm{HT} 2$ receptors as well, $^{43}$ this finding requires replication with more selective tracers. Moreover, no significant difference in the striatal D2/3 density was noted in nonpsychotic mania patients compared to $\mathrm{HC}^{44}$ These studies also explored the relationship between manic symptoms (as assessed using Young's Mania Rating Scale Score) and dopamine synthesis capacity and D2/3 density, finding no significant correlations between these variables in patients with mania. ${ }^{41,44,45}$ However, in one of these studies D2/3 density was directly correlated with psychosis scores on the present state examination. ${ }^{41}$ Taken together, these data suggest that psychotic symptoms in mania may be associated with dopaminergic abnormalities, although the same cannot be inferred in non-psychotic mania patients.

\section{Dopamine in euthymic BD}

Two studies have assessed dopamine transporters in the euthymic state and are conflicting. Chang et al reported an upregulation of the dopamine transporter in drug naive euthymic bipolar patients, while Anand et al. observed a downregulation in a group consisting of both euthymic bipolar and bipolar depression patients. ${ }^{46,47}$ Additionally, one study has assessed the vesicular monoamine transporter protein (VMAT-2), located in presynaptic neurons and involved in the storage of dopamine. There was an increase in VMAT-2 in the thalamus and dorsal brainstem, but no significant alteration in striatum, in currently euthymic patients with a history of psychotic mania compared with $\mathrm{HC}^{48}$ A positron emission tomography (PET) study using $\left[{ }^{11} \mathrm{C}\right]-\mathrm{SCH} 23390$ found decreased D1 density in the frontal cortex but not in the striatum of bipolar patients compared to $\mathrm{HC}$, suggesting a regional difference in D1 receptor distribution (Table 3). ${ }^{49}$

So far, only one PET study has assessed dopamine release in BD. This study used $\left[^{123} \mathrm{I}\right]$-IBZM to measure dopamine receptor density and release after amphetamine challenge in patients in their 


\begin{tabular}{|c|c|c|c|c|c|c|c|}
\hline $\begin{array}{l}\text { Dopamine } \\
\text { system studied }\end{array}$ & Author & $\begin{array}{l}\text { Patients/ } \\
\text { controls ( } \mathrm{n} \text { ) }\end{array}$ & $\begin{array}{l}\text { Phase of illness-number } \\
\text { of participants in the } \\
\text { given phase }\end{array}$ & Medication & Tracer* & $\begin{array}{l}\text { Primary outcome } \\
\text { In patients compared with controls }\end{array}$ & Secondary outcome \\
\hline $\begin{array}{l}\text { Dopamine } \\
\text { synthesis }\end{array}$ & $\begin{array}{l}\text { Yatham } \\
\text { et al. }{ }^{45}\end{array}$ & $13 / 14$ & $\begin{array}{l}\text { Mania (Non- } \\
\text { psychotic)-13 }\end{array}$ & Sodium valproate & {$\left[{ }^{18} \mathrm{~F}\right] \mathrm{DOPA}$} & $\begin{array}{l}\leftrightarrow \text { FDOPA uptake rate constants in } \\
\text { the striatum. } \\
\text { After } 2-6 \text { weeks treatment with } \\
\text { sodium valporate, FDOPA rate } \\
\text { constants }-\downarrow\end{array}$ & $\begin{array}{l}\text { No correlations were found } \\
\text { between YMRS and pre/post Ki } \\
\text { values }\end{array}$ \\
\hline \multirow[t]{3}{*}{$\begin{array}{l}\mathrm{D} 2 / 3 \text { receptor } \\
\text { availability }\end{array}$} & $\begin{array}{l}\text { Yatham } \\
\text { et al. }{ }^{44}\end{array}$ & $13 / 14$ & $\begin{array}{l}\text { Mania (Non- } \\
\text { psychotic)-13 }\end{array}$ & Sodium valproate & {$\left[{ }^{11} \mathrm{C}\right]$ raclopride } & $\begin{array}{l}\leftrightarrow \text { Striatal D2 density. } \\
\text { After } 2-6 \text { weeks of treatment with } \\
\text { sodium valproate no change in } \\
\text { striatal D2 density (10 patients had } \\
\text { second scan). }\end{array}$ & \multirow{3}{*}{$\begin{array}{l}\text { No correlation was found between } \\
\text { D2 density and score of young } \\
\text { mania rating scale. } \\
\text { Similarly changes in the D2 density } \\
\text { did not correlate with score in the } \\
\text { YMRS } \\
\text { D2 availability directly correlated } \\
\text { with psychotic symptom severity } \\
\text { score, but no correlation with } \\
\text { mania symptom rating }\end{array}$} \\
\hline & $\begin{array}{l}\text { Pearlson } \\
\text { et al. }\end{array}$ & $14 / 12$ & $\begin{array}{l}\text { Mania-11 } \\
\text { (6 psychotic mania) } \\
\text { Depression-3 }\end{array}$ & $\begin{array}{l}\text { All received two scans. } \\
\text { Second scan was } \\
\text { preceded by haloperidol } \\
\text { lactate }\end{array}$ & $\begin{array}{l}{\left[{ }^{11} \mathrm{C}\right] \mathrm{N}-} \\
\text { methylspiperone }\end{array}$ & $\begin{array}{l}\uparrow \mathrm{D} 2 \text { density in caudate and } \\
\text { putamen }\end{array}$ & \\
\hline & $\begin{array}{l}\text { Wong } \\
\text { et al. }\end{array}$ & $14 / 24$ & $\begin{array}{l}\text { Mania-11 (7 } \\
\text { psychotic) } \\
\text { Depression-3 }\end{array}$ & Drug naive & $\begin{array}{l}\mathrm{N}-\left[{ }^{11} \mathrm{C}\right] \\
\text { methylspiperone } \\
\left(\left[\left[^{11} \mathrm{C}\right] \mathrm{NMSP}\right)\right.\end{array}$ & $\begin{array}{l}\uparrow \mathrm{D} 2 \text { dopamine receptor density in } \\
\text { caudate were seen in psychotic } \\
\text { patients compared with non- } \\
\text { psychotic patients and healthy } \\
\text { controls }\end{array}$ & \\
\hline
\end{tabular}




\begin{tabular}{|c|c|c|c|c|c|c|c|}
\hline $\begin{array}{l}\text { Dopamine } \\
\text { system studied }\end{array}$ & Author & $\begin{array}{l}\text { Patients/ } \\
\text { controls (n) }\end{array}$ & $\begin{array}{l}\text { Phase of illness- } \\
\text { number of } \\
\text { participants in the } \\
\text { given phase }\end{array}$ & Medication & Tracer & $\begin{array}{l}\text { Primary outcome } \\
\text { In patients compared with } \\
\text { controls }\end{array}$ & Secondary outcome \\
\hline $\begin{array}{l}\text { Vesicular } \\
\text { monoamine } \\
\text { transporter } \\
\text { protein } \\
\text { (VMAT-2) }\end{array}$ & Zubieta et al. ${ }^{48}$ & $16 / 16$ & $\begin{array}{l}\text { Euthymic-16 } \\
\text { (history of } \\
\text { psychotic mania) }\end{array}$ & $\begin{array}{l}\text { Valproic acid; lithium; } \\
\text { carbamazepine; lamotrigine }\end{array}$ & $\begin{array}{l}{[11 C]} \\
\text { dihydrotetrabenazine } \\
\text { (DTBZ) }\end{array}$ & $\begin{array}{l}\stackrel{\leftrightarrow}{\text { Caudate }} \\
\uparrow \text { Brainstem and thalamus }\end{array}$ & $\begin{array}{l}\text { VMAT concentration in } \\
\text { brainstem and thalamus } \\
\text { positively correlated with the } \\
\text { measure of frontal executive } \\
\text { function }\end{array}$ \\
\hline $\begin{array}{l}\text { Dopamine } \\
\text { release }\end{array}$ & Anand et al. ${ }^{50}$ & $13 / 13$ & Euthymic-13 & $\begin{array}{l}7 \text { Drug naive and } 6 \text { were on mood } \\
\text { stabiliser: lithium (4) valproate (2). } \\
\text { After first scan patients were } \\
\text { administered amphetamine }\end{array}$ & {$\left[{ }^{123} I\right] I B Z M$} & $\begin{array}{l}\leftrightarrow \text { In amphetamine- } \\
\text { induced decrease in striatal } \\
{[123 \mid] \text { IBZM binding. }}\end{array}$ & $\begin{array}{l}\text { In patients, amphetamine- } \\
\text { induced decrease in [123I] IBZM } \\
\text { binding did not correlate with } \\
\text { post amphetamine YMRS score. } \\
\text { In healthy controls, there was } \\
\text { trend level correlation. }\end{array}$ \\
\hline \multirow[t]{3}{*}{$\begin{array}{l}\text { Dopamine } \\
\text { transporter }\end{array}$} & Anand et al. ${ }^{46}$ & $11 / 13$ & $\begin{array}{l}\text { Depressed-6 } \\
\text { Euthymic-5 }\end{array}$ & Drug naive & {$\left[{ }^{11} \mathrm{C}\right] \mathrm{CFT}$} & $\begin{array}{l}\downarrow D A T \text { availability in caudate } \\
\text { nucleus in patients }\end{array}$ & $\begin{array}{l}\text { No correlations were found } \\
\text { between YMRS/HDRS and D2 } \\
\text { binding }\end{array}$ \\
\hline & $\begin{array}{l}\text { Amsterdam and } \\
\text { Newberg }\end{array}$ & $5 / 46$ & Depression-5 & Drug naive for at least a week & $\begin{array}{l}{\left[{ }^{99} \mathrm{mTc}\right]} \\
\text { TRODAT-1 }\end{array}$ & $\begin{array}{l}\uparrow \text { Binding potential in the } \\
\text { posterior putamen and in } \\
\text { the left caudate region }\end{array}$ & \\
\hline & Chang et al. ${ }^{47}$ & $17 / 17$ & Euthymic-17 & Drug naive & {$\left[{ }^{99} \mathrm{mTc}\right]$ TRODAT-1 } & $\uparrow$ Striatal DAT availability & \multirow{3}{*}{$\begin{array}{l}\text { No significant difference in DAT } \\
\text { availability between bipolar I } \\
\text { and II. } \\
\text { In patients, amphetamine- } \\
\text { induced decrease in [123I] IBZM } \\
\text { binding did not correlate with } \\
\text { post amphetamine YMRS score. } \\
\text { In healthy controls, there was } \\
\text { trend level correlation }\end{array}$} \\
\hline D2/3 density & Anand et al. ${ }^{50}$ & $13 / 13$ & Euthymic-13 & $\begin{array}{l}7 \text { Drug naive and } 6 \text { were on mood } \\
\text { stabiliser: lithium (4) valproate (2). } \\
\text { After first scan patients were } \\
\text { administered amphetamine }\end{array}$ & {$\left[{ }^{123} \mid\right] \mid B Z M$} & $\begin{array}{l}\leftrightarrow \text { In striatal D2 receptor } \\
\text { binding at baseline. } \\
\leftrightarrow \text { In amphetamine- } \\
\text { induced decrease in striatal } \\
\text { [123I] IBZM binding. }\end{array}$ & \\
\hline D1 density & Suhara et al. ${ }^{49}$ & $10 / 21$ & $\begin{array}{l}\text { Depressed-3 } \\
\text { Manic-1 } \\
\text { Euthymic-6 }\end{array}$ & $\begin{array}{l}\text { All except one were drug naive for } \\
\text { at least one week before scan }\end{array}$ & {$\left[{ }^{11} \mathrm{C}\right]-\mathrm{SCH} 23390$} & $\begin{array}{l}\downarrow D 1 \text {, in the frontal } \\
\text { cortex } \leftrightarrow \text { striatum }\end{array}$ & \\
\hline
\end{tabular}




\begin{tabular}{|c|c|c|c|c|c|c|}
\hline \multirow[t]{2}{*}{ Phase of illness } & \multirow[t]{2}{*}{ Author } & \multirow[t]{2}{*}{$B D \mathrm{n}(\% M) / H C \mathrm{n}(\% M)^{\mathrm{a}}$} & \multirow[t]{2}{*}{ fMRI task } & \multicolumn{2}{|c|}{ VS 'reward' activity in $B D$ vs $H C$} & \multirow[t]{2}{*}{ Association with symptoms/dopamine antagonist medication } \\
\hline & & & & Anticipation & Feedback $^{\mathrm{a}}$ & \\
\hline \multirow[t]{2}{*}{ Manic } & Abler et al..$^{70}$ & $12 \mathrm{BD} \mathrm{I}(58.3) / 12 \mathrm{HC}(58.3)$ & $\begin{array}{l}\text { Monetary } \\
\text { incentive task }\end{array}$ & $\leftrightarrow$ VS & $\downarrow$ Left VS & \\
\hline & Bermpohl et al. ${ }^{71}$ & $15 \mathrm{BD} \mathrm{I}(53.3) / 26 \mathrm{HC}(57.7)$ & MID & $\leftrightarrow$ VS & $\leftrightarrow \mathrm{VS}$ & $\begin{array}{l}\text { No association with antidopaminergic medication. Remitted } \mathrm{BD}(n=7 \text {, } \\
\text { YMRS }<8) \text { OFC activation was similar to HC. }\end{array}$ \\
\hline \multirow[t]{7}{*}{ Euthymic } & Yip et al. ${ }^{82}$ & $\begin{array}{l}20 \mathrm{BD} I I / \mathrm{NOS}(60) / 20 \mathrm{HC} \\
(50)\end{array}$ & MID & $\leftrightarrow$ VS $(\downarrow$ r.DS $)$ & $\leftrightarrow$ VS & $\begin{array}{l}\text { No correlation between subsyndromal depressive symptoms (HDRS) } \\
\text { and reward-related BOLD signal. }\end{array}$ \\
\hline & Caseras et al. ${ }^{72}$ & $\begin{array}{l}17 \mathrm{BD} \mathrm{I}(36) / 15 \mathrm{BD} \text { II (40)/ } \\
20 \mathrm{HC}(35)\end{array}$ & $\begin{array}{l}\text { Card guessing } \\
\text { task }\end{array}$ & $\begin{array}{l}B D \text { I: } \leftrightarrow \text { VS } \\
B D \text { II: } \uparrow V S\end{array}$ & $\begin{array}{l}\text { BD I: } \uparrow \text { left VS } \\
\text { (trend) } \\
\text { BD II: } \leftrightarrow \text { VS }\end{array}$ & $\begin{array}{l}\text { During reward anticipation BD I had JVS activation vs BD II. At reward } \\
\text { feedback BD I had } \uparrow \text { activity in right VS vs BD II (not significant when } \\
\text { excluding patients taking antidopaminergic medication or co-varying } \\
\text { for medication load). VS activity not correlated with YMRS or HDRS. }\end{array}$ \\
\hline & Mason et al..$^{76}$ & $\begin{array}{l}20 \mathrm{BD}(18=\mathrm{BD} \mathrm{I}, 2=\mathrm{BD} I \mathrm{I}) \\
(50) / 20 \mathrm{HC}(45)\end{array}$ & Roulette task & †left VS (trend) & $\uparrow V S$ & $\begin{array}{l}\text { Preferential activity for high probability rewards negatively correlated } \\
\text { with impulsivity (DLPFC) and risk taking (DLPDC and VS) }\end{array}$ \\
\hline & Trost et al. ${ }^{81}$ & $16 \mathrm{BD}$ I (37.5)/16 HC (43.8) & $\begin{array}{l}\text { Desire-reason } \\
\text { dilemma }\end{array}$ & NA & $\downarrow V S$ & $\begin{array}{l}\text { Task-appropriate bilateral VS suppression in BD correlated with } \\
\text { antidopaminergic dose }\end{array}$ \\
\hline & Nusslock et al. ${ }^{77}$ & $21 \mathrm{BD} \mathrm{I}(42.9) / 20 \mathrm{HC}(40)$ & $\begin{array}{l}\text { Card guessing } \\
\text { task }\end{array}$ & $\uparrow$ Right VS & $\leftrightarrow$ VS & No association with antidopaminergic medication \\
\hline & Dutra et al. ${ }^{74}$ & 24 BD I (37.5)/25 HC (40) & $\begin{array}{l}\text { MID (no 'loss' } \\
\text { condition) }\end{array}$ & $\leftrightarrow \mathrm{VS}$ & $\uparrow V S$ & No association with antidopaminergic medication or symptom scores \\
\hline & Linke et al..$^{75}$ & $19 \mathrm{BD} \mathrm{I}(42.1) / 19 \mathrm{HC}(42.1)$ & Reversal learning & NA & $\leftrightarrow$ VS & $\begin{array}{l}\text { Negative correlation between medication load and mean activation } \\
\text { of the right amygdala in response to reward in } \mathrm{BD}\end{array}$ \\
\hline \multirow[t]{3}{*}{ Bipolar depression } & Chase et $a .^{73}$ & $23 \mathrm{BD} \mathrm{I}(17.4) / 37 \mathrm{HC}(32.4)$ & $\begin{array}{l}\text { Card guessing } \\
\text { task }\end{array}$ & $\leftrightarrow$ VS & $\leftrightarrow$ VS & $\begin{array}{l}\text { AP associated with } \downarrow \text { 'prediction error' VS signal. Illness duration } \\
\text { associated with } \downarrow A C C \text { reward anticipation activation }\end{array}$ \\
\hline & $\begin{array}{l}\text { Satterthwaite } \\
\text { et al. }\end{array}$ & $\begin{array}{l}23 \mathrm{BD}(21 \mathrm{BD} \mathrm{I}, 2 \mathrm{BD} I \mathrm{I}) \\
(37) / 32 \mathrm{HC}(51)\end{array}$ & $\begin{array}{l}\text { Monetary reward } \\
\text { task }\end{array}$ & NA & $\leftrightarrow$ VS & $\begin{array}{l}\text { BDI correlated with diminished reward-related (win > loss) activation } \\
\text { of bilateral VS, anterior and posterior cingulate, and anterior insula } \\
\text { No effect of antidopaminergic dose on reward-related BOLD signal }\end{array}$ \\
\hline & Redlich et al. ${ }^{78}$ & $33 \mathrm{BD} I(51.5) / 34 \mathrm{HC}(52.9)$ & $\begin{array}{l}\text { Card guessing } \\
\text { task }\end{array}$ & Not analysed & $\downarrow V S$ & No association with medication load or symptom scores \\
\hline Heterogeneous & Singh et al. ${ }^{80}$ & $\begin{array}{l}24 \text { adolescent BD1 (54)/ } \\
24 \mathrm{HC}(37)\end{array}$ & MID & $\leftrightarrow$ VS & $\leftrightarrow$ VS & $\begin{array}{l}\text { YMRS score associated with } \downarrow \text { VS activation during reward } \\
\text { anticipation, when MID was preceded by 'positive mood induction' }\end{array}$ \\
\hline
\end{tabular}


672

euthymic phase of illness, and found no significant differences between patients and $\mathrm{HC}^{50}$

\section{Dopamine in bipolar depression}

There is a paucity of literature on dopamine release and postsynaptic dopamine receptor density. Findings on dopamine transporter density remains controversial, with one study showing an increase in bipolar depressive patients when compared with HC, whilst the others, which recruited both euthymic and depressed patients, noted a reduction (Table 3)..$^{21,26}$

\section{DOPAMINE, REWARD PROCESSING AND BIPOLAR DISORDER:} FUNCTIONAL MAGNETIC RESONANCE IMAGING STUDIES

Dopaminergic projections from the VTA to the ventral striatum (VS) (including nucleus accumbens) and prefrontal cortex have an important role in reward processing ${ }^{51,52}$ and have also been implicated in the processing of other behaviourally salient stimuli. ${ }^{53,54}$ The word 'reward' implies three related functional elements: a positive reinforcer for learning, movement towards a desired object and subjective/emotional choices. The brain processes underlying reinforcement and movement can be quantitatively assessed using specific behavioural tasks and single cell or optogenetic recording in animals. ${ }^{55}$ Tasks that inform emotion per se are increasingly being performed in man but necessarily with less direct measures of neuronal activity.

Investigations in animals have shown that individual neurons signal reward-related information in the midbrain (substantia nigra and VTA), striatum, orbitofrontal cortex, amygdala and associated structures. Most dopamine neurons in the substantia nigra and VTA show brief, phasic responses that reflect the difference in value between received reward and predicted reward. The precise relationship between cell firing and function is still debated, but it would be misleading to think of dopamine neurotransmission simply in terms of a pleasure signal. ${ }^{56}$ Changes in BOLD signal occur in the human nucleus accumbens, striatum and frontal cortex over a time course of seconds in response to anticipated reward. ${ }^{57}$ Consistent with the animal literature, event-related functional magnetic resonance imaging (fMRI) reward paradigms have demonstrated robust activation of the ventral striatum in relation to both the anticipation and receipt of reward, ${ }_{1}^{58-61}$ presumably related to dopaminergic neurotransmission. ${ }^{57,62-69}$

In BD several fMRI studies employing reward tasks support the existence of abnormal reward-related neural activity in the VS and frontal cortex (task paradigms and results for VS summarised in Supplementary Table 2 and Table 4, respectively). ${ }^{61,70-82}$ This provides another indirect line of evidence for a dopaminergic abnormality in this disorder. We discuss the evidence in relation to specific mood polarities below.

\section{Bipolar mania}

During cued reward anticipation Abler et al. reported that medicated manic patients had reduced activity to high- vs noanticipated reward in the VTA, ${ }^{70}$ owing to increased neural activity for no-reward-predicting cues in BD patients. Three studies using monetary reward tasks found no difference in VS activation to cued reward anticipation between patients and controls. ${ }^{70,71,80}$ Two of these studies did, however, find elevated frontal cortex activity during reward anticipation in manic patients. ${ }^{71,80}$ During reward feedback Abler et al. reported reduced activity in response to receipt of probabilistic rewards in the VS in BD compared with $\mathrm{HC}^{70}$ This finding has not been replicated in more recent studies in patients with current manic symptoms ${ }^{71}$ or a recent manic episode. ${ }^{80}$

Together, these studies suggest hyperactive neuronal activity in putatively dopaminergic circuits of the reward system in currently manic patients, particularly during cue-induced reward anticipation. The precise nature of this abnormality, however, remains uncertain.

\section{Euthymic bipolar}

Euthymic patients are of particular interest because they are at risk of mania. In these patients abnormalities in dopaminergic function would then indicate how vulnerability might be mediated. In medicated euthymic bipolar I patients, VS and prefrontal cortex activity to cued reward anticipation has been variously reported as increased, ${ }^{76,77}$ and no different ${ }^{72,74}$ compared with controls. During reward feedback VS activity in euthymic bipolar I patients has been reported as increased, ${ }^{72,74,76}$ no different ${ }^{75,77}$ and decreased (in euthymic and mildly depressed patients), ${ }^{81}$ compared with controls. Reward feedback related activation in the frontal cortex has also variously been reported as elevated, ${ }^{75,76}$ decreased (in euthymic and mildly depressed patients) ${ }^{81}$ or no different $^{74,77}$ in bipolar I patients compared with controls. In euthymic bipolar II patients Caseras et al. reported elevated VS and prefrontal cortex activity for cued reward anticipation compared with controls. ${ }^{72}$ This finding, however, was not replicated in a more recent study of medication-naive bipolar II patients, which instead reported reduced anticipation-related activity in the right dorsal striatum in patients. ${ }^{82}$ Both studies reported no difference in VS activity during reward feedback in patients vs controls. Increased responses in the anticipatory phase of the monetary incentive delay task have been described in euthymic unipolar patients. ${ }^{83}$ Careful comparison of unipolar with bipolar cases will be necessary to distinguish network dysfunction associated with (hypo)mania from that with depression. All such studies need to be adequately powered and preferably address pre-specified hypotheses, not always a standard observed in imaging studies.

In summary, the precise nature of the abnormality of rewardrelated activity in euthymic bipolar patients remains unclear. However, abnormalities of reward processing are probably not confined to the manic phase of the illness. Important differences in task structure and the post hoc choice of analysis contrasts between these studies may account for the inconsistencies and non-replication. Further studies are required to explore the suggested differences between euthymic bipolar I, bipolar II and unipolar disorder.

\section{Bipolar depression}

Three studies have compared monetary reward processing in medicated depressed bipolar I patients and HC. Only one study analysed activity during cued reward anticipation; it reported no difference in anticipation-related activity between patients and $\mathrm{HC}$ in VS or prefrontal cortex, although there was blunting in the anterior cingulate cortex in depressed patients (bipolar and unipolar). Neural activity related to outcome anticipation per se was increased in left ventrolateral prefrontal cortex in patients with bipolar-1 disorder, compared with healthy controls or patients with unipolar depressive disorder; it may represent a more generalised 'arousal' response in the bipolar depressed group. ${ }^{73}$ Ventral striatal and prefrontal activation during reward feedback in bipolar depressive patients has been reported both as similar to controls ${ }^{73,79}$ and decreased. ${ }^{78}$

Recent fMRI studies and meta-analyses have demonstrated blunted activation of the reward network in the ventral striatum and frontal cortex in schizophrenia, ${ }^{84-86}$ as well as major depressive disorder and alcohol addiction. ${ }^{84}$ In contrast, the fMRI findings in bipolar disorder summarised above do not provide consistent evidence for blunting. It may be important to consider only studies in the manic state, because depressed or even euthymic (often dysthymic) bipolar patients may well show blunting. ${ }^{82}$ In mania there was increased frontal activation to 
Table 5. Summary of pharmacological evidence on dopamine dysfunction in the bipolar disorder

\begin{tabular}{|c|c|c|c|}
\hline Phase of illness & Drug & Mechanism of action & Effect \\
\hline \multirow{3}{*}{ Mania } & Amphetamine & Increases dopamine release & $\begin{array}{l}\text { Induced mania-like symptom in healthy } \\
\text { volunteers }\end{array}$ \\
\hline & Dietary tyrosine depletion & Reduces dopamine level & Reduced manic symptoms in patients \\
\hline & Antidopaminergics & D2 blockers & Reduces manic symptoms \\
\hline \multirow[t]{2}{*}{ Euthymia } & Olanzapine, quetiapine and ziprasidone & D2 blockade and $5 \mathrm{HT}$ agonism & Prolongs remission \\
\hline & Mood stabilisers & $\begin{array}{l}\text { Act on dopamine downstream } \\
\text { pathways }\end{array}$ & Prolongs remission \\
\hline \multirow[t]{2}{*}{ Depression } & Pramipexole & $\mathrm{D} 2 / 3$ agonist & Short-term efficacy in bipolar depression \\
\hline & Methylphenidate and amphetamine & Increase dopamine release & $\begin{array}{l}\text { Beneficial in group of bipolar depression patients } \\
\text { with drowsiness and fatigue }\end{array}$ \\
\hline
\end{tabular}

reward anticipation in two out of three studies. If this finding is confirmed in further studies, including direct comparisons with patients with schizophrenia, it could point to a key difference in the reward network between mania and schizophrenia. To date a small number of studies have compared reward processing in bipolar disorder with schizophrenia ${ }^{70}$ or major depressive disorder. $^{73,78}$ Of these, one study reported blunted VS activation in depressed patients diagnosed with bipolar disorder compared with major depressive disorder, at reward feedback. ${ }^{78}$ Only one study compared reward processing in schizophrenia and manic patients with controls. ${ }^{70}$ Patients with schizophrenia and healthy controls showed an activation in the VTA on expectation of monetary rewards and nucleus accumbens activation during receipt vs omission of rewards. Manic patients, however, showed reduced differential activation in the nucleus accumbens on receipt vs omission of rewards compared to the healthy control subjects. Taken together with the findings in the frontal cortex discussed above, this small study does suggest that in mania there is a deficit in prediction error processing not seen in schizophrenia. It may further imply bipolar disorder specific changes in dopaminergic function, although how much of the fMRI response is driven by disrupted dopaminergic function remains to be determined. Further studies investigating differences in reward processing between bipolar disorder and other psychotic and affective disorders, and across illness phases, will shed light on the reward processing abnormalities specific to bipolar disorder.

\section{PHARMACOLOGICAL EVIDENCE}

Dopaminergic manipulations and the induction of mania The role of dopaminergic abnormalities in BD has been extensively investigated using a variety of pharmacological approaches (Table 5). Firstly, studies have shown that psychostimulants, particularly amphetamine, cause mania-like symptoms in healthy volunteers. ${ }^{87-90}$ Further, there are several case series of manic and hypomanic episodes in Parkinson's disease patients treated with Levodopa. ${ }^{91-93}$ Bromocriptine, another dopamine agonist, has also been shown to induce manic symptoms. ${ }^{94,95}$ Similarly, an increased risk of hypomania/mania was observed in bipolar patients who received stimulant (methylphenidate, amphetamine or modafinil) augmentation for bipolar depression. ${ }^{96}$ Secondly, pharmacological strategies to deplete tyrosine, a dopamine precursor, are known to reduce manic symptoms, although it remains to be established if this is specifically due to reducing dopamine levels. ${ }^{97,98}$ Alpha-methylp-tyrosine, which induces dopamine depletion by inhibition of tyrosine hydroxylase, also attenuates mania-like symptom in bipolar patients. ${ }^{99,100}$

Dopaminergic manipulations and the induction of bipolar depression

Reserpine and tetrabenazine depletes synaptic dopamine by irreversibly inhibiting vesicular uptake of monoamines and has long been known to induce depression. ${ }^{101,102}$ In addition, a high prevalence of depression is seen in patients with Parkinson's disease and this has been linked to loss of striatal dopaminergic innervation. ${ }^{103,104}$ Finally, depletion of tyrosine has been shown to precipitate depressive symptoms in remitted patients with a history of major depressive disorder. ${ }^{105,106}$

\section{MODULATION OF THE DOPAMINE SYSTEM AND TREATMENT OF BIPOLAR DISORDER}

Antidopaminergic drugs in the treatment of mania

Dopamine antagonists and partial agonists are increasingly used in the treatment of acute mania, bipolar depression and also as maintenance treatment. ${ }^{107-110}$ Olanzapine, risperidone, quetiapine, aripiprazole, asenapine, ziprasidone and cariprazine have been approved by the Food and Drug Administration (FDA) as monotherapy for the treatment of acute mania. ${ }^{111}$ Pertinently, a network meta-analysis of 68 randomised controlled trials (RCT), involving 16073 participants, addressed the efficacy of different drugs in the treatment of acute mania. This showed that dopamine antagonists have larger effect sizes (Haloperidol (standardised mean difference (SMD) relative to placebo: -0.56 $(95 \% \mathrm{Cl}-0.69$ to -0.43$)$ ), risperidone $(-0.50(-0.63$ to -0.38$)$ ), olanzapine $(-0.43(-0.54$ to -0.32$))$ than mood stabilisers for the treatment of acute mania (lithium) $(-0.37(-0.63$ to -0.11$)$ ), carbamazepine $(-0.36(-0.60$ to -0.11$))$, valproate $(-0.20(-0.37$ to -0.04$))^{14}$

As the blockade of the dopamine D2/3 receptors is their common mechanism of action, ${ }^{24}$ it is likely that reduced dopamine neurotransmission at least contributes to the clinical efficacy of these drugs. This assumption is supported by the greater efficacy of the cis- but not the trans-isomer of clopenthixol in the treatment of manic symptoms, ${ }^{112}$ as the cis-isomer is a high 


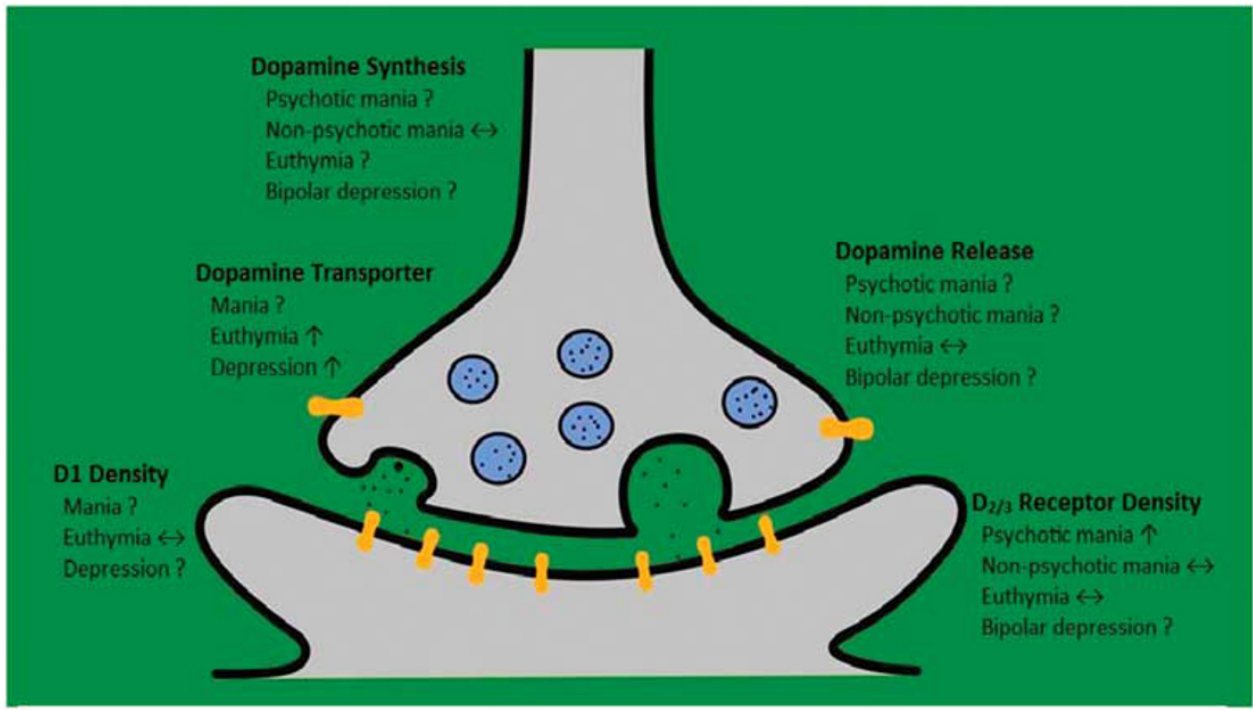

Figure 1. Summary of dopamine molecular imaging findings in bipolar disorder.

affinity D2/3 receptor blocker while the trans-isomer has much lower affinity for $\mathrm{D} 2 / 3$ receptors. ${ }^{44,112}$

Use of antidopaminergic in the maintenance phase

The FDA have approved olanzapine as monotherapy, quetiapine and ziprasidone as adjunctive therapy, and aripiprazole and risperidone long acting injections as both adjunctive and monotherapy for the maintenance treatment of BD. ${ }^{111}$ Although lithium and valproate should be preferred, recent guidelines highlight that dopaminergic drugs have a place in maintenance treatment. $^{113}$

Action of non-D2/3 blocker mood stabilisers on dopamine pathways

Interestingly, it is possible that sodium valproate might exhibit antimanic effect through an action on the dopaminergic system. ${ }^{44,45}$ In a study consisting of 13 manic patients, 2 weeks of sodium valproate was shown to decrease presynaptic dopamine synthesis capacity, ${ }^{45}$ although this was not correlated with clinical improvement. Interestingly D2/3 density remained essentially unchanged after valproate treatment, ${ }^{44}$ despite the reduction in dopamine synthesis capacity with valproate, which is anticipated to alter D2/3 availability. Taken together these two could either suggest valproate blocks the capacity of the D2 receptor to respond to reduced dopamine synthesis, or that the capacity of D2 receptors to respond is intrinsically impaired in bipolar disorder. Although both possibilities are speculative at this stage, the latter is particularly interesting as it suggests that a failure of D2 adaptation could contribute to the pathophysiology of bipolar disorder, making the dopamine system more vulnerable to dopamine transporter driven changes in presynaptic function.

Although the exact mechanism by which lithium acts remains unclear, it is known to modulate signalling pathways downstream of dopamine receptors. Preclinical studies have shown that lithium reverses dopamine dependent behaviour by acting through the protein kinase B (AKT)/glycogen synthase kinase 3 signalling cascade. ${ }^{114}$ Furthermore, lithium acts on the adenyl cyclase and phospho-inositide, as well as protein kinase $C$ pathways, which are part of the intracellular signalling pathway downstream of dopamine receptors. ${ }^{115}$ In addition, micro-dialysis studies show a reduction in extracellular dopamine levels in lithium treated animals. ${ }^{116-118}$ In summary, there is evidence to suggest that some non-D2/3 blocking mood stabilisers also act to reduce dopamine transmission, either through reducing presynaptic dopamine synthesis capacity in the case of sodium valproate, or post-synaptic dopaminergic signal transduction in the case of lithium. The degree to which these effects explain the therapeutic efficacy of these compounds remains to be determined.

\section{Use of dopaminergic treatments for bipolar depression}

Three double-blind placebo-controlled studies have shown that short-term use of pramipexole, a D2/D3 receptor agonist, is efficacious as an augmentation strategy for the treatment of bipolar depression and positive results have also been seen in other open-label studies. ${ }^{119-127}$ Although there have not been any RCTs investigating the efficacy of methylphenidate or amphetamines in bipolar depression, the available open-label and naturalistic studies point towards a benefit of stimulants in a selected group of patients with drowsiness and fatigue. ${ }^{128-131}$ Randomised controlled studies and open-label reports with other stimulant like agents such as modafinil and its R-enantiomer, armodafinil also indicate efficacy in bipolar depression although the development programme for armodafinil failed. ${ }^{132-138}$ There is evidence to support the potential use of monoamine oxidase inhibitors such as tranylcypromine in bipolar depression. ${ }^{139,140}$ It is speculated that tranylcypromine acts as dopamine releaser with about $1 / 10$ th the potency of amphetamine. ${ }^{139,140}$ There are thus several lines of evidence suggesting that dopaminergic augmentation is beneficial in bipolar depression.

However, there is also evidence that dopamine antagonists are effective in the treatment of bipolar depression. ${ }^{15}$ The FDA has approved the combination of olanzapine and fluoxetine, as well as monotherapy with quetiapine or lurasidone, for the treatment of acute bipolar depression. A recent meta-analysis of 24 placebocontrolled trails $(n=7307)$ revealed the following order of efficacy of drugs for the treatment of bipolar depression: olanzapine +fluoxetine $\geqslant$ valproate $>$ quetiapine $>$ lurasidone $>$ olanzapine, aripiprazole and carbamazepine. ${ }^{141}$ The analysis is interesting in showing that antidopaminergics on their own have efficacy in bipolar depression.

The evidence thus suggests that both dopaminergic agonists and dopaminergic blockers, are effective in treating bipolar depression. This presents a paradox for understanding the role of dopamine in bipolar depression. However, actions at receptors 
Box 1 Future research direction

1. Animal models exhibiting bipolar depression-like phenotype need to be developed.

2. Development of better animal models of mood polarity switching coupled with longitudinal, translational assays (such as PET, fMRI and behavioural methods).

3. Longitudinal molecular imaging studies investigating dopaminergic function, particularly dopamine transporter and D2/3 receptor homoeostasis, in patients across different illness phases.

4. Trans-diagnostic comparisons of dopaminergic function in psychotic and non-psychotic mania and schizophrenia.

5. Imaging studies in mixed states and rapid cycling bipolar disorder.

6. Longitudinal studies investigating the effects of antidopaminergic and conventional mood stabilisers on dopaminergic pathways and the relationship between dopaminergic blockade and treatment response in bipolar disorder.

7. Future studies should also focus on integration of data from molecular imaging studies with functional MRI to elucidate specific anatomical circuits involved and the link to molecular changes.

8. Molecular imaging studies should investigate extra-striatal dopaminergic changes across different phases of bipolar disorder.

Abbreviations: $\mathrm{fMRI}$, functional magnetic resonance imaging PET, positron emission tomography.

other than dopamine ones may underlie the efficacy of the dopamine blockers. For example, as well as all being D2/3 receptor blockers, olanzapine and quetiapine are both relatively high affinity $5 \mathrm{HT}_{2 \mathrm{~A}}$ antagonists, ${ }^{142}$ whilst both lurasidone and aripiprazole have high affinity for $5 \mathrm{HT}_{1 \mathrm{~A}}$ receptors. ${ }^{142,143}$ Potentially supporting this explanation, there are no clinical trials reporting efficacy of pure D2/3 blockers in bipolar depression. Nevertheless, the doses used in the clinical trials correspond to the dose ranges associated with substantial dopamine D2/3 receptor occupancy, ${ }^{24}$ so dopamine receptor blockade is certainly compatible with antidepressant efficacy. The final consideration is that there has been a relatively small number of good quality RCTs for antidopaminergic treatment in bipolar depression, certainly in comparison to studies in mania. Studies that can directly test the mechanism underlying the mode of action of these drugs and pramipexole would be of great interest.

\section{DISCUSSION}

Our main findings for bipolar mania are that (i) there is consistent pharmacological evidence, especially from treatment studies, to support the hypothesis that a state of hyperdopaminergia can lead to mania; (ii) imaging studies support this hypothesis, with several studies reporting elevations in D2/3 receptor availability in psychotic mania and $\mathrm{fMRI}$ imaging evidence that identifies hyperactivity of the reward circuit in mania. Dopamine synthesis and receptor density appear to remain unchanged, at least in nonpsychotic mania patients compared with HC.

For bipolar depression (i) pharmacological evidence shows that dopamine agonists are potentially beneficial for bipolar depression, but the same seems true for dopamine blocking drugs; (ii) the imaging studies show replicated increases in dopamine transporter levels, but there is inconsistency and it is not clear if there are other alterations as well. Figure 1 summarises our main imaging findings for mania and depression.

Finally, post-mortem evidence suggests an upregulation of the D2/3 receptors in bipolar patients, but interpretation is limited by lack of information on phase of illness and medication status at the time of death.

Implications for the dopamine hypothesis of bipolar disorder More than four decades on from the early conceptualisations of the dopamine hypothesis of $\mathrm{BD}$, it has stood the test of time, and the evidence for elements have strengthened. This is particularly the case for mania where the strength of the clinical trial evidence for the benefit of dopamine antagonists and partial agonists, supported by meta-analysis, would require an improbably large number of negative studies for reversal. Added to this there is now molecular and fMRI imaging evidence in bipolar disorder. Further, preclinical studies using optogenetic methods and knockout mice have shown that dopaminergic neuron activation leads to manic-like behaviour and it is linked to circadian gene expression. ${ }^{31,144}$ Tentatively, these studies suggest elevated D2/3 receptor availability and a hyper-responsive reward system in ventral striatum in mania, and an increase in striatal dopamine transporter availability in bipolar depression. Dopamine neurotransmission in the striatum is primarily terminated by reuptake of dopamine into the presynaptic dopamine nerve terminal by dopamine transporters. Thus, an elevation in striatal D2/3 receptor availability in mania would lead to increased dopaminergic neurotransmission whilst increased striatal dopamine transporter levels in depression would lead to reduced dopaminergic function. This suggests a model in which elevated D2/3 receptor levels lead to altered reward processing and the development of mania, which is followed by a compensatory increase in dopamine transporter levels to reduce dopaminergic neurotransmission. However, if, over time, D2/3 receptor levels reduce but dopamine transporter levels do not normalise, this would then lead to reduced dopaminergic transmission, leading to depression and, in turn, a compensatory upregulation of D2/3 receptor levels, precipitating a further phase switch. One can see how a failure of homoeostatic regulation of the dopaminergic system could lead to cyclical periods of elevated and blunted dopaminergic neurotransmission. This model might apply most precisely to rapid cycling bipolar disorder. However it could be a component of all manic episodes, with other systems acting to disrupt the regular cyclicity that is so obvious in a substantial number of patients.

We recognise that this model is conjectural at this stage. Nevertheless, it makes predictions that can be tested empirically. In particular it predicts longitudinal changes in dopamine transporter and receptor levels linked to phase switches. Moreover it predicts that these changes and alterations in reward processing will pre-date symptom changes. However, many aspects of dopamine function in bipolar disorder are incompletely characterised. In particular baseline dopamine levels have not been measured in mania or depression. In addition, psychotic symptoms may also be present in manic patients, and psychosis per se may drive dopaminergic changes. ${ }^{40,145}$ It is worth noting that, none of the studies have investigated dopamine function in mixed states. As approximately two thirds of depressed patients have concomitant manic symptoms, ${ }^{146}$ any theory needs to explain mixed states as well as mania and depression. It would be hard to account for mixed states by dysfunction in dopaminergic function alone. Interestingly, asenapine seems to be more effective than olanzapine for mixed episodes. ${ }^{147}$ As asenapine has higher affinity for $5 \mathrm{HT} 2 \mathrm{~A}$ than D2/3 receptors, which could suggest a role of serotonergic system in mixed episode states. Finally elevations in $D_{2 / 3}$ receptor availability would be predicted to increase dopaminergic neurotransmission via the indirect 
pathway, and reduce response to cues, ${ }^{148}$ while the $\mathrm{fMRI}$ findings in mania do not seem to fit with this. However, the majority of the patients in these studies were treated with dopamine antagonists and mood stabilisers (Supplementary Table 2), which confounds simple interpretation of effects based on dopamine neurotransmission.

\section{Implications for treatment}

If dopamine transmission is increased in mania, the use of D2/3 receptor blockers is logical, but alternative approaches, such as reducing dopamine synthesis and/or release, are alternative approaches that may be more effective and/or better tolerated if they could be sufficiently selective. Similarly, selective DAT blockade could be beneficial for BD depression, at the risk of precipitating mania. Finally mood stabilisation should improve homoeostatic regulation of dopaminergic neurotransmission, and this requires further evaluation and understanding.

\section{Limitations and future directions}

The key limitation of the dopamine hypothesis remains that its strongest supporting evidence comes from pharmacological studies, which offer an indirect and sometimes imprecise approach to studying dopaminergic function. Reserpine, alphamethyl-para-tyrosine, amphetamine and L-DOPA, for example, can affect neurotransmission of other monoamines, in particular norepinephrine, which could contribute to the clinical effects observed. By the same token, the efficacy of antidopaminergic drugs in mania may be due to actions at other neurotransmitter systems, although relatively selective dopamine blockers do appear to be effective. There is a relative paucity of evidence from more direct measures, such as molecular imaging studies, and thus conclusions remain tentative at this stage. Earlier molecular imaging studies on D2/3 density in mania were conducted using non-selective ligand $\left[{ }^{11} \mathrm{C}\right] \mathrm{N}$-methylspiperone, which has affinity to both $\mathrm{D} 2 / 3$ and $5 \mathrm{HT} 2 \mathrm{~A}$ receptors. ${ }^{149}$ Interpretation is further complicated by some studies not being restricted to one illness phase. Moreover, none of the studies addressed dopamine transporter availability in mania, dopamine release in mania or dopamine release in bipolar depression (summarised in Figure 1).

Although our model suggests euthymia is a state of normalised dopamine, based on a study demonstrating no significant alteration in the dopamine release paradigm in euthymic patients compared to controls, ${ }^{50}$ this is not consistent with the finding of elevated DAT in a euthymic state. ${ }^{47}$ It also remains unclear whether the dopamine hypothesis can completely explain bipolar depression and how dopaminergic dysregulation will be linked to the involvement of other neurotransmitter systems.

A critical limitation is the lack of longitudinal studies that investigate changes across phases of illness, including mixed states. Ideally future studies should focus on elucidating phaserelated dopamine dysfunction by studying patients longitudinally in euthymic, manic and depressive episodes to determine the direction of causality. Clearly this will be difficult, although a focus on rapid cycling patients might make it feasible. Cross-sectional studies are more feasible and could test key elements of the dopamine hypothesis if well designed. Another key issue is why some antidopaminergics are effective for bipolar depression. Molecular imaging studies are needed to determine whether dopaminergic, serotonergic or other systems are involved in their mode of action. Finally, although studies have found an effect of valproate and lithium on dopaminergic function, ${ }^{44,115}$ it is not established if this is their mechanism of action. Determining whether dopaminergic mechanisms are common across classes of medication would be an important advance in understanding. Finally, it remains unclear if hyperdopaminergic activity is specific to mania or psychosis because many of the manic patients in the studies had psychotic symptoms as well. It is interesting to note that in schizophrenia molecular imaging studies indicate there is an elevation in dopamine synthesis and release capacity, but unaltered dopamine transporter and D2/3 receptor availability in striatum. ${ }^{40}$ PET studies have also demonstrated elevated striatal dopamine turnover, but blunted cortical and midbrain dopamine release in schizophrenia. ${ }^{150}$ In addition, blunting of the fMRI signal during reward tasks is observed in schizophrenia. ${ }^{85}$ In contrast, studies in bipolar disorder suggest dopamine synthesis capacity is unaltered, at least in non-psychotic mania, but there is elevated D2/3 receptor availability in psychotic mania. However, direct comparisons of dopaminergic function in psychotic mania and schizophrenia as well as longitudinal studies of dopaminergic activity across various phases of illness are needed to determine if there are differences between mania and schizophrenia, and between mania and bipolar depression (Box 1).

\section{CONCLUSIONS}

The dopamine hypothesis of bipolar disorder proposes that faulty homoeostasis between dopamine transporter and receptors underlies depressive and manic phases of the illness. The available evidence suggests elevated D2/3 receptor availability and a hyperresponsive reward system in mania, and possibly increased dopamine transporter availability in bipolar depression. Future longitudinal studies are needed to elucidate the precise phaserelated changes in dopaminergic function and the specificity of alterations to mania over psychosis.

\section{CONFLICT OF INTEREST}

The authors declare no conflict of interest.

\section{ACKNOWLEDGMENTS}

AHA, TRM and MMN conduct research funded by the Medical Research Council (UK). TRM received honoraria as a speaker for Lundbeck. SJ conducts research funded by Medical Research Council (UK) and Wellcome trust. Professor Howes conducts research funded by the Medical Research Council (UK), the National Institute of Health Research (UK) and the Maudsley Charity. Professor Goodwin holds a grant from Wellcome Trust, holds shares in P1vital and has served as consultant, advisor or CME speaker for AstraZeneca, Merck, Cephalon/Teva, Eli Lilly, Lundbeck, Medscape, Otsuka, P1Vital, Pfizer, Servier, Sunovion, Takeda. He is a NIHR Senior Investigator. Professor Young has been a consultant to or has received honoraria or grants from AstraZeneca, Lunbeck, Eli Lilly, Janssen, Servier, Sunovion, Cyberonics and Wyeth. $\mathrm{ODH}$ has received investigator-initiated research funding from and/or participated in advisory/speaker meetings organised by AstraZeneca, BMS, Eli Lilly, Jansenn, Lundbeck, Lyden-Delta, Servier, and Roche. The views expressed are those of the author(s) and not necessarily those of the NHS, the NIHR or the Department of Health.

\section{REFERENCES}

1 Judd LL, Akiskal HS, Schettler PJ, Endicott J, Leon AC, Solomon DA et al. Psychosocial disability in the course of bipolar I and II disorders: a prospective, comparative, longitudinal study. Arch Gen Psychiatry 2005; 62: 1322-1330.

2 Judd LL, Schettler PJ, Solomon DA, Maser JD, Coryell W, Endicott J et al. Psychosocial disability and work role function compared across the long-term course of bipolar I, bipolar II and unipolar major depressive disorders. J Affect Disord 2008; 108: 49-58.

3 Vos T, Flaxman AD, Naghavi M, Lozano R, Michaud C, Ezzati M et al. Years lived with disability (YLDs) for 1160 sequelae of 289 diseases and injuries 1990-2010: a systematic analysis for the Global Burden of Disease Study 2010. Lancet 2012; 380: 2163-2196.

4 Merikangas KR, Cui L, Kattan G, Carlson GA, Youngstrom EA, Angst J. Mania with and without depression in a community sample of US adolescents. Arch Gen Psychiatry 2012; 69: 943-951.

5 Merikangas KR, Jin R, He JP, Kessler RC, Lee S, Sampson NA et al. Prevalence and correlates of bipolar spectrum disorder in the world mental health survey initiative. Arch Gen Psychiatry 2011; 68: 241-251.

6 Grande I, Berk M, Birmaher B, Vieta E. Bipolar disorder. Lancet 2015; 387: 1561-1572. 
7 Dilsaver SC. An estimate of the minimum economic burden of bipolar I and II disorders in the United States: 2009. J Affect Disord 2011; 129: 79-83.

8 Jann MW. Diagnosis and treatment of bipolar disorders in adults: a review of the evidence on pharmacologic treatments. Am Health Drug Benefits 2014; 7: 489-499.

9 Alda M. Lithium in the treatment of bipolar disorder: pharmacology and pharmacogenetics. Mol Psychiatry 2015; 20: 661-670.

10 Geddes JR, Burgess S, Hawton K, Jamison K, Goodwin GM. Long-term lithium therapy for bipolar disorder: systematic review and meta-analysis of randomized controlled trials. Am J Psychiatry 2004; 161: 217-222.

11 Gitlin M. Treatment-resistant bipolar disorder. Mol Psychiatry 2006; 11: 227-240.

12 Ketter TA, Miller S, Dell'Osso B, Wang PW. Treatment of bipolar disorder: review of evidence regarding quetiapine and lithium. J Affect Disord 2016; 191: 256-273.

13 Severus E, Taylor MJ, Sauer C, Pfennig A, Ritter P, Bauer M et al. Lithium for prevention of mood episodes in bipolar disorders: systematic review and meta-analysis. Int J Bipolar Disord 2014; 2: 15.

14 Cipriani A, Barbui C, Salanti G, Rendell J, Brown R, Stockton S et al. Comparative efficacy and acceptability of antimanic drugs in acute mania: a multipletreatments meta-analysis. Lancet 2011; 378: 1306-1315.

15 Young AH, McElroy SL, Olausson B, Paulsson B. A randomised, placebocontrolled 52-week trial of continued quetiapine treatment in recently depressed patients with bipolar I and bipolar II disorder. World J Biol Psychiatry 2014; 15: $96-112$.

16 Giles JJ, Bannigan JG. Teratogenic and developmental effects of lithium. Curr Pharm Des 2006; 12: 1531-1541.

17 Gentile S. Lithium in pregnancy: the need to treat, the duty to ensure safety. Expert Opin Drug Saf 2012; 11: 425-437.

18 McKnight RF, Adida M, Budge K, Stockton S, Goodwin GM, Geddes JR. Lithium toxicity profile: a systematic review and meta-analysis. Lancet 2012; 379: 721-728.

19 Tissot R. The common pathophysiology of monaminergic psychoses: a new hypothesis. Neuropsychobiology 1975; 1: 243-260.

20 Wittenborn JR. Deductive approaches to the catecholamine hypothesis of affective disorders. J Nerv Ment Dis 1974; 158: 320-324.

21 Singh MM. A unifying hypothesis on the biochemical basis of affective disorder. Psychiatr Q 1970; 44: 706-724.

22 Berk M, Dodd S, Kauer-Sant'anna M, Malhi GS, Bourin M, Kapczinski F et al. Dopamine dysregulation syndrome: implications for a dopamine hypothesis of bipolar disorder. Acta Psychiatr Scand Suppl 2007; (434): 41-49.

23 Cousins DA, Butts $\mathrm{K}$, Young $\mathrm{AH}$. The role of dopamine in bipolar disorder. Bipolar Disord 2009; 11: 787-806.

24 Howes OD, Egerton A, Allan V, McGuire P, Stokes P, Kapur S. Mechanisms underlying psychosis and antipsychotic treatment response in schizophrenia: insights from PET and SPECT imaging. Curr Pharm Des 2009; 15: 2550-2559.

25 Harrison PJ, Cipriani A, Harmer CJ, Nobre AC, Saunders K, Goodwin GM et al. Innovative approaches to bipolar disorder and its treatment. Ann N Y Acad Sci 2016; 1366: 76-89.

26 Berggren U, Tallstedt L, Ahlenius S, Engel J. The effect of lithium on amphetamineinduced locomotor stimulation. Psychopharmacology 1978; 59: 41-45.

27 Gould TJ, Keith RA, Bhat RV. Differential sensitivity to lithium's reversal of amphetamine-induced open-field activity in two inbred strains of mice. Behav Brain Res 2001; 118: 95-105.

28 Perry W, Minassian A, Paulus MP, Young JW, Kincaid MJ, Ferguson EJ et al. A reverse-translational study of dysfunctional exploration in psychiatric disorders: from mice to men. Arch Gen Psychiatry 2009; 66: 1072-1080.

29 Young JW, Goey AK, Minassian A, Perry W, Paulus MP, Geyer MA. The mania-like exploratory profile in genetic dopamine transporter mouse models is diminished in a familiar environment and reinstated by subthreshold psychostimulant administration. Pharmacol Biochem Behav 2010; 96: 7-15.

30 Shaldubina A, Einat $\mathrm{H}$, Szechtman $\mathrm{H}$, Shimon $\mathrm{H}$, Belmaker RH. Preliminary evaluation of oral anticonvulsant treatment in the quinpirole model of bipolar disorder. J Neural Transm 2002; 109: 433-440.

31 Sidor MM, Spencer SM, Dzirasa K, Parekh PK, Tye KM, Warden MR et al. Daytime spikes in dopaminergic activity drive rapid mood-cycling in mice. Mol Psychiatry 2015; 20: 1406-1419.

32 Winter C, von Rumohr A, Mundt A, Petrus D, Klein J, Lee T et al. Lesions of dopaminergic neurons in the substantia nigra pars compacta and in the ventral tegmental area enhance depressive-like behavior in rats. Behav Brain Res 2007; 184: 133-141.

33 Tye KM, Mirzabekov JJ, Warden MR, Ferenczi EA, Tsai HC, Finkelstein J et al. Dopamine neurons modulate neural encoding and expression of depressionrelated behaviour. Nature 2013; 493: 537-541.

34 Kaalund SS, Newburn EN, Ye T, Tao R, Li C, Deep-Soboslay A et al. Contrasting changes in DRD1 and DRD2 splice variant expression in schizophrenia and affective disorders, and associations with SNPs in postmortem brain. Mol Psychiatry 2014; 19: 1258-1266.

35 Zhan L, Kerr JR, Lafuente MJ, Maclean A, Chibalina MV, Liu B et al. Altered expression and coregulation of dopamine signalling genes in schizophrenia and bipolar disorder. Neuropathol Appl Neurobiol 2011; 37: 206-219.

36 Glantz LA, Gilmore JH, Overstreet DH, Salimi K, Lieberman JA, Jarskog LF. Pro-apoptotic Par-4 and dopamine D2 receptor in temporal cortex in schizophrenia, bipolar disorder and major depression. Schizophr Res 2010; 118: 292-299.

37 Pantazopoulos $\mathrm{H}$, Stone D, Walsh J, Benes FM. Differences in the cellular distribution of D1 receptor mRNA in the hippocampus of bipolars and schizophrenics. Synapse 2004; 54: 147-155.

38 Knable MB, Barci BM, Webster MJ, Meador-Woodruff J, Torrey EF. Molecular abnormalities of the hippocampus in severe psychiatric illness: postmortem findings from the Stanley Neuropathology Consortium. Mol Psychiatry 2004; 9 : 544.

39 Ginovart N, Wilson AA, Hussey D, Houle S, Kapur S. D2-receptor upregulation is dependent upon temporal course of D2-occupancy: a longitudinal [11C]-raclopride PET study in cats. Neuropsychopharmacology 2009; 34: 662-671.

40 Howes OD, Kambeitz J, Kim E, Stahl D, Slifstein M, Abi-Dargham A et al. The nature of dopamine dysfunction in schizophrenia and what this means for treatment. Arch Gen Psychiatry 2012; 69: 776-786.

41 Pearlson GD, Wong DF, Tune LE, Ross CA, Chase GA, Links JM et al. In vivo D2 dopamine receptor density in psychotic and nonpsychotic patients with bipolar disorder. Arch Gen Psychiatry 1995; 52: 471-477.

42 Wong DF, Pearlson GD, Tune LE, Young LT, Meltzer CC, Dannals RF et al. Quantification of neuroreceptors in the living human brain: IV. Effect of aging and elevations of D2-like receptors in schizophrenia and bipolar illness. J Cereb Blood Flow Metab 1997; 17: 331-342.

43 Swart JA, van der Werf JF, Wiegman T, Paans AM, Vaalburg W, Korf J. In vivo binding of spiperone and $\mathrm{N}$-methylspiperone to dopaminergic and serotonergic sites in the rat brain: multiple modeling and implications for PET scanning. J Cereb Blood Flow Metab 1990; 10: 297-306.

44 Yatham LN, Liddle PF, Lam RW, Shiah IS, Lane C, Stoessl AJ et al. PET study of the effects of valproate on dopamine $D(2)$ receptors in neuroleptic- and moodstabilizer-naive patients with nonpsychotic mania. Am J Psychiatry 2002; 159: 1718-1723.

45 Yatham LN, Liddle PF, Shiah IS, Lam RW, Ngan E, Scarrow G et al. PET study of [(18)F]6-fluoro-L-dopa uptake in neuroleptic- and mood-stabilizer-naive first-episode nonpsychotic mania: effects of treatment with divalproex sodium. Am J Psychiatry 2002; 159: 768-774.

46 Anand A, Barkay G, Dzemidzic M, Albrecht D, Karne H, Zheng QH et al. Striatal dopamine transporter availability in unmedicated bipolar disorder. Bipolar Disord 2011; 13: 406-413.

47 Chang TT, Yeh TL, Chiu NT, Chen PS, Huang HY, Yang YK et al. Higher striatal dopamine transporters in euthymic patients with bipolar disorder: a SPECT study with [Tc] TRODAT-1. Bipolar Disord 2010; 12: 102-106.

48 Zubieta JK, Huguelet P, Ohl LE, Koeppe RA, Kilbourn MR, Carr JM et al. High vesicular monoamine transporter binding in asymptomatic bipolar I disorder: sex differences and cognitive correlates. Am J Psychiatry 2000; 157: 1619-1628.

49 Suhara T, Nakayama K, Inoue O, Fukuda H, Shimizu M, Mori A et al. D1 dopamine receptor binding in mood disorders measured by positron emission tomography. Psychopharmacology 1992; 106: 14-18.

50 Anand A, Verhoeff P, Seneca N, Zoghbi SS, Seibyl JP, Charney DS et al. Brain SPECT imaging of amphetamine-induced dopamine release in euthymic bipolar disorder patients. Am J Psychiatry 2000; 157: 1108-1114.

51 Berridge KC. From prediction error to incentive salience: Mesolimbic computation of reward motivation. Eur J Neurosci 2012; 35: 1124-1143.

52 Schultz W. Dopamine signals for reward value and risk: basic and recent data Behav Brain Funct 2010; 6: 1-9.

53 Winton-Brown TT, Fusar-Poli $P$, Ungless MA, Howes OD. Dopaminergic basis of salience dysregulation in psychosis. Trends Neurosci 2014; 37: 85-94.

54 Howes OD, Nour MM. Dopamine and the aberrant salience hypothesis of schizophrenia. World Psychiatry 2016; 15: 3-4.

55 Tsai HC, Zhang F, Adamantidis A, Stuber GD, Bonci A, de Lecea L et al. Phasic firing in dopaminergic neurons is sufficient for behavioral conditioning. Science2009; 324: 1080-1084.

56 Schultz W. Updating dopamine reward signals. Curr Opin Neurobiol 2013; 23: 229-238.

57 Schott BH, Minuzzi L, Krebs RM, Elmenhorst D, Lang M, Winz $\mathrm{OH}$ et al. Mesolimbic functional magnetic resonance imaging activations during reward anticipation correlate with reward-related ventral striatal dopamine release. J Neurosci 2008; 28: 14311-14319. 
58 Bartra O, McGuire JT, Kable JW. The valuation system: a coordinate-based metaanalysis of BOLD fMRI experiments examining neural correlates of subjective value. Neurolmage 2013; 76: 412-427.

59 Diekhof EK, Kaps L, Falkai P, Gruber O. The role of the human ventral striatum and the medial orbitofrontal cortex in the representation of reward magnitude an activation likelihood estimation meta-analysis of neuroimaging studies of passive reward expectancy and outcome processing. Neuropsychologia 2012; 50: $1252-1266$.

60 Liu X, Hairston J, Schrier M, Fan J. Common and distinct networks underlying reward valence and processing stages: a meta-analysis of functional neuroimaging studies. Neurosci Biobehav Rev 2011; 35: 1219-1236.

61 Nusslock R, Young CB, Damme KSF. Elevated reward-related neural activation as a unique biological marker of bipolar disorder: assessment and treatment implications. Behav Res Therapy 2014; 62: 74-87.

62 Aarts E, Roelofs A, Franke B, Rijpkema M, Fernandez G, Helmich RC et al. Striatal dopamine mediates the interface between motivational and cognitive control in humans: evidence from genetic imaging. Neuropsychopharmacology 2010; 35: 1943-1951.

63 Dreher JC, Kohn P, Kolachana B, Weinberger DR, Berman KF. Variation in dopamine genes influences responsivity of the human reward system. Proc Natl Acad Sci USA 2009; 106: 617-622.

64 Forbes EE, Brown SM, Kimak M, Ferrell RE, Manuck SB, Hariri AR. Genetic variation in components of dopamine neurotransmission impacts ventral striatal reactivity associated with impulsivity. Mol Psychiatry 2009; 14: 60-70.

65 Jonasson LS, Axelsson J, Riklund K, Braver TS, Ogren M, Backman L et al. Dopamine release in nucleus accumbens during rewarded task switching measured by [(1)(1)C]raclopride. Neurolmage 2014; 99: 357-364.

66 Schultz W. Multiple dopamine functions at different time courses. Annu Rev Neurosci 2007; 30: 259-288.

67 van der Schaaf ME, van Schouwenburg MR, Geurts DE, Schellekens AF, Buitelaar JK, Verkes $\mathrm{RJ}$ et al. Establishing the dopamine dependency of human striatal signals during reward and punishment reversal learning. Cereb Cortex 2014; 24: 633-642.

68 Knutson B, Gibbs SEB. Linking nucleus accumbens dopamine and blood oxygenation. Psychopharmacology 2007; 191: 813-822.

69 Pessiglione M, Seymour B, Flandin G, Dolan RJ, Frith CD. Dopamine-dependent prediction errors underpin reward-seeking behaviour in humans. Nature 2006; 442: 1042-1045.

70 Abler B, Greenhouse I, Ongur D, Walter H, Heckers S. Abnormal reward system activation in mania. Neuropsychopharmacology 2008; 33: 2217-2227.

71 Bermpohl F, Kahnt T, Dalanay U, Hägele C, Sajonz B, Wegner T et al. Altered representation of expected value in the orbitofrontal cortex in Mania. Hum Brain Mapp 2010; 31: 958-969.

72 Caseras X, Lawrence NS, Murphy K, Wise RG, Phillips ML. Ventral striatum activity in response to reward: differences between bipolar $\mathrm{i}$ and II disorders. Am J Psychiatry 2013; 170: 533-541.

73 Chase HW, Nusslock R, Almeida JR, Forbes EE, Labarbara EJ, Phillips ML. Dissociable patterns of abnormal frontal cortical activation during anticipation of an uncertain reward or loss in bipolar versus major depression. Bipolar Disord 2013; 15: 839-854.

74 Dutra S, Cunningham W, Kober H, Gruber J. Elevated striatal reactivity across monetary and social rewards in bipolar I disorder. J Abnorm Psychol 2015; 124: 890-904.

75 Linke J, King AV, Rietschel M, Strohmaier J, Hennerici M, Gass A et al. Increased medial orbitofrontal and amygdala activation: evidence for a systems-level endophenotype of bipolar I disorder. Am J Psychiatry 2012; 169: 316-325.

76 Mason L, O'Sullivan N, Montaldi D, Bentall RP, El-Deredy W. Decision-making and trait impulsivity in bipolar disorder are associated with reduced prefrontal regulation of striatal reward valuation. Brain 2014; 137: 2346-2355.

77 Nusslock R, Almeida J, Forbes E, Versace A, Frank E, LeBarbara E et al. Waiting to win: elevated striatal and orbitofrontal cortical activity during reward anticipation in euthymic bipolar disorder adults. Bipolar Disord 2012; 14: 249-260.

78 Redlich R, Dohm K, Grotegerd D, Opel N, Zwitserlood P, Heindel W et al. Reward processing in unipolar and bipolar depression: a functional MRI study. Neuropsychopharmacology 2015; 40: 1-28.

79 Satterthwaite TD, Kable JW, Vandekar L, Katchmar N, Bassett DS, Baldassano CF et al. Common and dissociable dysfunction of the reward system in bipolar and unipolar depression reward dysfunction in depression. Neuropsychopharmacology 2015; 40: 1-11.

80 Singh MK, Chang KD, Kelley RG, Cui X, Sherdell L, Howe ME et al. Reward processing in adolescents with bipolar I disorder. J Am Acad Child Adolesc Psychiatry 2013; 52: 68-83.

81 Trost S, Diekhof EK, Zvonik K, Lewandowski M, Usher J, Keil M et al. Disturbed anterior prefrontal control of the mesolimbic reward system and increased impulsivity in bipolar disorder. Neuropsychopharmacology 2014; 39: 1914-1923.
82 Yip SW, Worhunsky PD, Rogers RD, Goodwin GM. Hypoactivation of the ventral and dorsal striatum during reward and loss anticipation in antipsychotic and mood stabilizer-naive bipolar disorder. Neuropsychopharmacology 2015; 40: 658-666.

83 Dichter GS, Kozink RV, McClernon FJ, Smoski MJ. Remitted major depression is characterized by reward network hyperactivation during reward anticipation and hypoactivation during reward outcomes. J Affect Disord 2012; 136: 1126-1134.

84 Hagele C, Schlagenhauf F, Rapp M, Sterzer P, Beck A, Bermpohl F et al. Dimensional psychiatry: reward dysfunction and depressive mood across psychiatric disorders. Psychopharmacology 2015; 232: 331-341.

85 Radua J, Schmidt A, Borgwardt S, Heinz A, Schlagenhauf F, McGuire P et al. Ventral striatal activation during reward processing in psychosis: a neurofunctional meta-analysis. JAMA Psychiatry 2015; 72: 1243-1251.

86 Yan C, Yang T, Yu QJ, Jin Z, Cheung EF, Liu X et al. Rostral medial prefrontal dysfunctions and consummatory pleasure in schizophrenia: a meta-analysis of functional imaging studies. Psychiatry Res 2015; 231: 187-196.

87 Asghar SJ, Tanay VA, Baker GB, Greenshaw A, Silverstone PH. Relationship of plasma amphetamine levels to physiological, subjective, cognitive and biochemical measures in healthy volunteers. Hum Psychopharm 2003; 18: 291-299.

88 Silverstone T. Dopamine in manic depressive illness. A pharmacological synthesis. J Affect Disord 1985; 8: 225-231.

89 Jacobs $\mathrm{D}$, Silverstone T. Dextroamphetamine-induced arousal in human subjects as a model for mania. Psychol Med 1986; 16: 323-329.

90 Nurnberger JI Jr., Gershon ES, Simmons S, Ebert M, Kessler LR, Dibble ED et al. Behavioral, biochemical and neuroendocrine responses to amphetamine in normal twins and 'well-state' bipolar patients. Psychoneuroendocrinology 1982; 7: $163-176$

91 Ko GN, Leckman JF, Heninger GR. Induction of rapid mood cycling during L-dopa treatment in a bipolar patient. Am J Psychiatry 1981; 138: 1624-1625.

92 Harsch HH, Miller M, Young LD. Induction of mania by L-dopa in a nonbipolar patient. J Clin Psychopharmacol 1985; 5: 338-339.

93 Murphy DL. L-dopa, behavioral activation and psychopathology. Res Publ Assoc Res Nerv Ment Dis 1972; 50: 472-493.

94 Fisher G, Pelonero AL, Ferguson C. Mania precipitated by prednisone and bromocriptine. Gen Hosp Psychiatry 1991; 13: 345-346.

95 Kemperman CJ, Zwanikken GJ. Psychiatric side effects of bromocriptine therapy for postpartum galactorrhoea. J R Soc Med 1987; 80: 387-388.

96 Wingo AP, Ghaemi SN. Frequency of stimulant treatment and of stimulantassociated mania/hypomania in bipolar disorder patients. Psychopharmacol Bull 2008; 41: 37-47.

97 McTavish SF, McPherson MH, Harmer CJ, Clark L, Sharp T, Goodwin GM et al. Antidopaminergic effects of dietary tyrosine depletion in healthy subjects and patients with manic illness. Br J Psychiatry 2001; 179: 356-360.

98 Scarna A, Gijsman HJ, McTavish SF, Harmer CJ, Cowen PJ, Goodwin GM. Effects of a branched-chain amino acid drink in mania. Br J Psychiatry 2003; 182: 210-213.

99 Anand A, Darnell A, Miller HL, Berman RM, Cappiello A, Oren DA et al. Effect of catecholamine depletion on lithium-induced long-term remission of bipolar disorder. Biol Psychiatry 1999; 45: 972-978.

100 van Enkhuizen J, Geyer MA, Halberstadt AL, Zhuang X, Young JW. Dopamine depletion attenuates some behavioral abnormalities in a hyperdopaminergic mouse model of bipolar disorder. J Affect Disord 2014; 155: 247-254.

101 Schildkraut JJ. The catecholamine hypothesis of affective disorders: a review of supporting evidence. Am J Psychiatry 1965; 122: 509-522.

102 Kenney C, Hunter C, Mejia N, Jankovic J. Is history of depression a contraindication to treatment with tetrabenazine? Clin Neuropharmacol 2006; 29: 259-264.

103 Martinez-Martin P, Damian J. Parkinson disease: depression and anxiety in Parkinson disease. Nat Rev Neurol 2010; 6: 243-245.

104 Remy P, Doder M, Lees A, Turjanski N, Brooks D. Depression in Parkinson's disease: loss of dopamine and noradrenaline innervation in the limbic system. Brain 2005; 128: 1314-1322.

105 Parker G, Brotchie $\mathrm{H}$. Mood effects of the amino acids tryptophan and tyrosine: 'Food for Thought' III. Acta Psychiatr Scand 2011; 124: 417-426.

106 Ruhe HG, Mason NS, Schene AH. Mood is indirectly related to serotonin, norepinephrine and dopamine levels in humans: a meta-analysis of monoamine depletion studies. Mol Psychiatry 2007; 12: 331-359.

107 Greil W, Haberle A, Haueis P, Grohmann R, Russmann S. Pharmacotherapeutic trends in 2231 psychiatric inpatients with bipolar depression from the International AMSP Project between 1994 and 2009. J Affect Disord 2012; 136: 534-542.

108 Hayes J, Prah P, Nazareth I, King M, Walters K, Petersen I et al. Prescribing trends in bipolar disorder: cohort study in the United Kingdom THIN primary care database 1995-2009. PloS One 2011: 6: e28725.

109 Hooshmand F, Miller S, Dore J, Wang PW, Hill SJ, Portillo $\mathrm{N}$ et al. Trends in pharmacotherapy in patients referred to a bipolar specialty clinic, 2000-2011. J Affect Disord 2014; 155: 283-287. 
110 Walpoth-Niederwanger M, Kemmler G, Grunze H, Weiss U, Hortnagl C, Strauss R et al. Treatment patterns in inpatients with bipolar disorder at a psychiatric university hospital over a 9-year period: focus on mood stabilizers. Int Clin Psychopharmacol 2012; 27: 256-266.

111 Ketter TA, Miller S, Dell'Osso B, Calabrese JR, Frye MA, Citrome L. Balancing benefits and harms of treatments for acute bipolar depression. J Affect Disord 2014; 169: S24-S33.

112 Nolen WA. Dopamine and mania. The effects of trans- and cis-clopenthixol in a double-blind pilot study. J Affect Disord 1983; 5: 91-96.

113 Goodwin GM, Haddad PM, Ferrier IN, Aronson JK, Barnes T, Cipriani A et al. Evidence-based guidelines for treating bipolar disorder: Revised third edition recommendations from the British Association for Psychopharmacology. J Psychopharmacol 2016; 30: 495-553.

114 Beaulieu JM, Sotnikova TD, Yao WD, Kockeritz L, Woodgett JR, Gainetdinov RR et al. Lithium antagonizes dopamine-dependent behaviors mediated by an AKT/glycogen synthase kinase 3 signaling cascade. Proc Natl Acad Sci USA 2004; 101: 5099-5104.

115 Malhi GS, Tanious M, Das P, Coulston CM, Berk M. Potential mechanisms of action of lithium in bipolar disorder. Current understanding. CNS Drugs 2013; 27: 135-153.

116 Gambarana C, Ghiglieri O, Masi F, Scheggi S, Tagliamonte A, De Montis MG. The effects of long-term administration of rubidium or lithium on reactivity to stress and on dopamine output in the nucleus accumbens in rats. Brain Res 1999; 826: 200-209.

117 Ichikawa J, Dai J, Meltzer HY. Lithium differs from anticonvulsant mood stabilizers in prefrontal cortical and accumbal dopamine release: role of $5-\mathrm{HT}(1 \mathrm{~A})$ receptor agonism. Brain Res 2005; 1049: 182-190.

118 Ferrie LJ, Gartside SE, Martin KM, Young AH, McQuade R. Effect of chronic lithium treatment on D2/3 autoreceptor regulation of dopaminergic function in the rat. Pharmacol Biochem Behav 2008; 90: 218-225.

119 Burdick KE, Braga RJ, Nnadi CU, Shaya Y, Stearns WH, Malhotra AK. Placebocontrolled adjunctive trial of pramipexole in patients with bipolar disorder: targeting cognitive dysfunction. J Clin Psychiatry 2012; 73: 103-112.

120 Cassano P, Lattanzi L, Soldani F, Navari S, Battistini G, Gemignani A et al. Pramipexole in treatment-resistant depression: an extended follow-up. Depress Anxiety 2004; 20: 131-138.

121 Dell'osso B, Timtim S, Hooshmand F, Miller S, Wang PW, Hill SJ et al. Superior chronic tolerability of adjunctive modafinil compared to pramipexole in treatment-resistant bipolar disorder. J Affect Disord 2013; 150: 130-135.

122 El-Mallakh RS, Penagaluri P, Kantamneni A, Gao Y, Roberts RJ. Long-term use of pramipexole in bipolar depression: a naturalistic retrospective chart review. Psychiatr Q 2010; 81: 207-213.

123 Goldberg JF, Burdick KE, Endick CJ. Preliminary randomized, double-blind, placebo-controlled trial of pramipexole added to mood stabilizers for treatmentresistant bipolar depression. Am J Psychiatry 2004; 161: 564-566.

124 Lattanzi L, Dell'Osso L, Cassano P, Pini S, Rucci P, Houck PR et al. Pramipexole in treatment-resistant depression: a 16-week naturalistic study. Bipolar Disord 2002; 4: 307-314.

125 Perugi G, Toni C, Ruffolo G, Frare F, Akiskal H. Adjunctive dopamine agonists in treatment-resistant bipolar II depression: an open case series. Pharmacopsychiatry 2001; 34: 137-141.

126 Sporn J, Ghaemi SN, Sambur MR, Rankin MA, Recht J, Sachs GS et al. Pramipexole augmentation in the treatment of unipolar and bipolar depression: a retrospective chart review. Ann Clin Psychiatry 2000; 12: 137-140.

127 Zarate CA Jr., Payne JL, Singh J, Quiroz JA, Luckenbaugh DA, Denicoff KD et al. Pramipexole for bipolar II depression: a placebo-controlled proof of concept study. Biol Psychiatry 2004; 56: 54-60.

128 Carlson PJ, Merlock MC, Suppes T. Adjunctive stimulant use in patients with bipolar disorder: treatment of residual depression and sedation. Bipolar Disord 2004; 6: 416-420.

129 El-Mallakh RS. An open study of methylphenidate in bipolar depression. Bipolar Disord 2000; 2: 56-59.

130 Lydon E, El-Mallakh RS. Naturalistic long-term use of methylphenidate in bipolar disorder. J Clin Psychopharmacol 2006; 26: 516-518.

131 Parker G, Brotchie $\mathrm{H}$. Do the old psychostimulant drugs have a role in managing treatment-resistant depression? Acta Psychiatr Scand 2010; 121: 308-314.
132 Goss AJ, Kaser M, Costafreda SG, Sahakian BJ, Fu CH. Modafinil augmentation therapy in unipolar and bipolar depression: a systematic review and metaanalysis of randomized controlled trials. J Clin Psychiatry 2013; 74: 1101-1107.

133 Dell'Osso B, Ketter TA, Cremaschi L, Spagnolin G, Altamura AC. Assessing the roles of stimulants/stimulant-like drugs and dopamine-agonists in the treatment of bipolar depression. Curr Psychiatry Rep 2013; 15: 378.

134 Rao JS, Kellom M, Reese EA, Rapoport SI, Kim HW. Dysregulated glutamate and dopamine transporters in postmortem frontal cortex from bipolar and schizophrenic patients. J Affect Disord 2012; 136: 63-71.

135 Lee FJ, Pei L, Liu F. Disruption of the dopamine transporter-dopamine D2 receptor interaction in schizophrenia. Synapse (New York, NY) 2009; 63: 710-712.

136 Amsterdam JD, Newberg AB. A preliminary study of dopamine transporter binding in bipolar and unipolar depressed patients and healthy controls. Neuropsychobiology 2007; 55: 167-170.

137 Nasr S. Modafinil as adjunctive therapy in depressed outpatients. Ann Clin Psychiatry 2004; 16: 133-138.

138 Nasr S, Wendt B, Steiner K. Absence of mood switch with and tolerance to modafinil: a replication study from a large private practice. J Affect Disord 2006; 95: $111-114$

139 Heijnen WT, De Fruyt J, Wierdsma Al, Sienaert P, Birkenhager TK. Efficacy of tranylcypromine in bipolar depression: a systematic review. J Clin Psychopharmacol 2015; 35: 700-705.

140 Shulman Kl, Herrmann N, Walker SE. Current place of monoamine oxidase inhibitors in the treatment of depression. CNS Drugs 2013; 27: 789-797.

141 Selle V, Schalkwijk S, Vazquez GH, Baldessarini RJ. Treatments for acute bipolar depression: meta-analyses of placebo-controlled, monotherapy trials of anticonvulsants, lithium and antipsychotics. Pharmacopsychiatry 2014; 47: 43-52.

142 Farah A. Atypicality of atypical antipsychotics. Prim Care Companion J Clin Psychiatry 2005; 7: 268-274.

143 Meyer JM, Loebel AD, Schweizer E. Lurasidone: a new drug in development for schizophrenia. Expert Opin Investig Drugs 2009; 18: 1715-1726.

144 Chung S, Lee EJ, Yun S, Choe HK, Park SB, Son HJ et al. Impact of circadian nuclear receptor REV-ERBalpha on midbrain dopamine production and mood regulation. Cell 2014; 157: 858-868.

145 Fusar-Poli $\mathrm{P}$, Howes OD, Allen P, Broome M, Valli I, Asselin MC et al. Abnorma prefrontal activation directly related to pre-synaptic striatal dopamine dysfunction in people at clinical high risk for psychosis. Mol Psychiatry 2011; 16: 67-75.

146 Goldberg JF, Perlis RH, Bowden CL, Thase ME, Miklowitz DJ, Marangell LB et al. Manic symptoms during depressive episodes in 1,380 patients with bipolar disorder: findings from the STEP-BD. Am J Psychiatry 2009; 166: 173-181.

147 Berk M, Tiller JW, Zhao J, Yatham LN, Malhi GS, Weiller E. Effects of asenapine in bipolar I patients meeting proxy criteria for moderate-to-severe mixed major depressive episodes: a post hoc analysis. J Clin Psychiatry 2015; 76: 728-734.

148 Hazy TE, Frank MJ, O'Reilly RC. Neural mechanisms of acquired phasic dopamine responses in learning. Neurosci Biobehav Rev 2010; 34: 701-720.

149 Hall H, Wedel I, Halldin C, Kopp J, Farde L. Comparison of the in vitro receptor binding properties of $\mathrm{N}-[3 \mathrm{H}]$ methylspiperone and $[3 \mathrm{H}]$ raclopride to rat and human brain membranes. J Neurochem 1990; 55: 2048-2057.

150 Slifstein M, van de Giessen E, Van Snellenberg J, Thompson JL, Narendran R, Gil R et al. Deficits in prefrontal cortical and extrastriatal dopamine release in schizophrenia: a positron emission tomographic functional magnetic resonance imaging study. JAMA Psychiatry 2015; 72: 316-324.

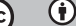

This work is licensed under a Creative Commons Attribution 4.0 International License. The images or other third party material in this article are included in the article's Creative Commons license, unless indicated otherwise in the credit line; if the material is not included under the Creative Commons license, users will need to obtain permission from the license holder to reproduce the material. To view a copy of this license, visit http://creativecommons.org/licenses/ by/4.0/

(c) The Author(s) 2017

Supplementary Information accompanies the paper on the Molecular Psychiatry website (http://www.nature.com/mp) 